\title{
Fra-2 overexpression upregulates pro-metastatic cell-adhesion molecules, promotes pulmonary metastasis, and reduces survival in a spontaneous xenograft model of human breast cancer
}

\author{
Sabrina Arnold ${ }^{1}$. Jan Kortland' - Diana V. Maltseva ${ }^{2}$ Stepan A. Nersisyan ${ }^{2} \cdot$ Timur R. Samatov $^{4} \cdot$ Susanne Lezius $^{5}$. \\ Alexander G. Tonevitsky ${ }^{2,3} \cdot$ Karin Milde-Langosch $^{6} \cdot$ Daniel Wicklein $^{1} \cdot$ Udo Schumacher $^{1} \cdot$ Christine Stürken $^{1}$
}

Received: 3 June 2021 / Accepted: 22 August 2021 / Published online: 24 October 2021

(c) The Author(s) 2021

\begin{abstract}
Purpose The transcription factor Fra-2 affects the invasive potential of breast cancer cells by dysregulating adhesion molecules in vitro. Previous results suggested that it upregulates the expression of E- and P-selectin ligands. Such selectin ligands are important members of the leukocyte adhesion cascade, which govern the adhesion and transmigration of cancer cells into the stroma of the host organ of metastasis. As so far, no in vivo data are available, this study was designed to elucidate the role of Fra-2 expression in a spontaneous breast cancer metastasis xenograft model.

Methods The effect of Fra-2 overexpression in two stable Fra-2 overexpressing clones of the human breast cancer cell line MDA MB231 on survival and metastatic load was studied after subcutaneous injection into scid and E- and P-selectindeficient scid mice.

Results Fra-2 overexpression leads to a significantly shorter overall survival and a higher amount of spontaneous lung metastases not only in scid mice, but also in E- and P-deficient mice, indicating that it regulates not only selectin ligands, but also selectin-independent adhesion processes.

Conclusion Thus, Fra-2 expression influences the metastatic potential of breast cancer cells by changing the expression of adhesion molecules, resulting in increased adherence to endothelial cells in a breast cancer xenograft model.
\end{abstract}

Keywords Breast cancer $\cdot$ Transcription factor $\cdot$ AP- $1 \cdot$ Fra- $2 \cdot$ Metastasis

\section{Introduction}

Breast cancer is the most frequent form of cancer in women and the most common cause of female cancer death (Eccles et al. 2013). Metastasized breast cancer still represents a considerable clinical problem, as it cannot ultimately be cured and thus most patients die because of the metastatic spread to vital organs such as lung, bone marrow, and liver (Pantel and Brakenhoff 2004). To achieve progress in the treatment of metastasized breast cancer, a better understanding of the process of metastasis formation is therefore necessary. During distant metastasis formation, cancer cells

Sabrina Arnold and Jan Kortland have contributed equally to this work.

\section{Christine Stürken}

c.stuerken@uke.de

Extended author information available on the last page of the article first of all separate from the primary tumour and invade the local stroma, enter the tumour blood vessels, and are transported through the circulation to distant sites. Here, adhesion to endothelial cells and extravasation into the stroma of the secondary site follows, where some of the emigrated cells eventually grow into clinically detectable metastases (Carr and Orr 1983; Fidler 1978, 2003). Endothelial cells at this site express E- and P-selectins at their luminal surface, which have been previously described as mediators of the first step of leucocyte adhesion and transmigration at sites of inflammation. Comparable with leucocyte adhesion, studies have demonstrated an involvement of selectins in the attachment and transmigration of circulating tumour cells (Gout et al. 2008; Tremblay et al. 2006). The particular contribution of selectin expression to cancer progression is defined by the temporal and spatial presence of selectins on the luminal endothelial cell surface but also on the presence of selectin ligands on the cancer cell membrane (Borsig 2018). The classical (canonical) binding partners of selectins are 
carbohydrate structures, which must be presented on specialized protein scaffolds that enhance ligand clustering, which enables effective selectin binding (Varki 1997). Enhanced selectin ligand expression on tumour cells enables the contact with the endothelium and thereby regulates tumour cell progression (Borsig 2018).

In a foregoing study, we demonstrated that the overexpression of the transcription factor Fra-2 (FOSL2 or Fosrelated antigen-2) in MDA MB231 cells resulted in altered in vitro expression of cell-adhesion molecules involved in cell-cell or cell-matrix interactions and investigated the adhesive potential of these transfected cells. A strong increase of transiently adherent (rolling) cells compared with the control cells was observed in laminar flow assays with E-selectin coated surfaces, indicating that Fra-2 overexpression upregulates expression of cell-adhesion molecules or their ligands, respectively, of the leukocyte adhesion cascade (Schroder et al. 2010). In particular, the observation that increased Fra-2 expression can lead to increased attachment of the cancer cells to E-selectin suggests that Fra-2 also modulates selectin-binding sites in breast cancer cells in vivo and thus allows the tumour cells to adhere to the vascular endothelium via E-selectin.

The expression of these cell-adhesion molecules and their ligands underlies the regulation by transcription factors including Fra-2. Fra-2 (Fos-related antigen-2) is part of the AP-1 (activating protein-1) transcription factor complex, consisting of the Fos-, Jun-, ATF-, and MAF-protein families (Angel and Karin 1991; Eferl and Wagner 2003; Goetz et al. 1996; Vogt and Bos 1990) that bind to regulatory sequences of various target genes, which in turn are induced by growth factors, cytokines, oncoproteins, or tumour promoters like TPA (12-O-tetradecanoylphorbol-13-acetate). They form hetero- or homodimers, whose respective combination determines the genes that are regulated by AP-1 (Eferl and Wagner 2003). Initially, Fra-2 was thought to be primarily involved in bone formation (Bozec et al. 2013) and appeared to be associated with several different physiological and pathological processes, such as photoperiodic regulation (Engel et al. 2005) or fibrosis (Roy et al. 2010). In addition, further studies have shown that Fra-2 might play a pivotal role in the progression of diverse human tumour types in vivo (Milde-Langosch 2005). Fra-2 overexpression was found in salivary gland tumours (Maruya et al. 2004), colorectal cancer (Zhang et al. 2005), adult T-cell leukaemia (Nakayama et al. 2008), cutaneous T-cell lymphomas (Nakayama et al. 2012), and tongue cancer (Gupta et al. 2015). Although breast cancer is probably the most intensively studied tumour entity in terms of the role of AP-1 members in malignant progression, still considerably uncertainties about the function of Fra- 2 expression in breast cancer exist. So far, only one study has shown that in breast cancer, overexpression of Fra- 2 is associated with a more aggressive tumour phenotype, suggesting that Fra-2 may be involved in breast cancer progression in vivo (Milde-Langosch et al. 2008).

It was also recently shown that Fra-2 facilitates TGFB1-induced migration in non-small cell lung cancer (NSCLC) cells by interaction with the transcription factor Smad3 (Wang et al. 2014). Due to these multiple interactions, Fra-2 is an ideal candidate, which can possibly exert a regulatory effect on the expression of many different celladhesion molecules and their ligands, respectively. We therefore wanted to investigate which of these regulatory effects of Fra- 2 operate in an in vivo model of breast cancer metastasis and focused on E- and P-selectin-binding sites as the first receptors of the leukocyte adhesion cascade. By studying the effect of Fra-2 overexpression in MDA MB231 breast cancer cells in scid mice and E- and P-selectin-deficient mice, we investigated the role of this transcription factor in tumor cell adhesion and metastasis in vivo. By comparison of tumor xenografts in both mouse models, we further analysed the role of selectins from both the ligand and the receptor sides during this process.

\section{Materials and methods}

\section{Cell lines}

All cells derived from the human breast cancer cell line MDA MB231 were cultivated as described before (MildeLangosch et al. 2008) and stable clones with increased Fra-2 expression had been generated by transfections with the plasmid Fra-2-pIRES containing the full Fra-2 cDNA cloned in the bicistronic vector pIRES (Milde-Langosch et al. 2008). For the following experiments, the MDA-Fra-2 clones (cl) 1 and 2 and the MDA-pIRES clone as negative control were used. All cell lines were routinely tested for mycoplasma infection using the PCR-based VenorGeM Mycoplasma Detection kit (Minerva Biolaps GmBH, Berlin, Germany) according to the manufacturer's instructions. Only cells negative for mycoplasma infection were used for further experiments. Authenticity of human cell lines has been confirmed by STR analysis (DSMZ Braunschweig, Germany).

\section{Subcutaneous xenograft mouse model}

In this study, female Balb/c severe combined immunodeficient (scid) mice as well as E-selectin -/- and P-selectin $-/-$ scid mice were used. Scid mice had been crossbred with E- and P-selectin-deficient mice (Jackson laboratory, stock no: 002916) and selectin deficiency was verified as described previously (Stubke et al. 2012). The mice were housed under pathogen-free conditions in IVC cages and 
provided with sterile food and water ad libitum. For injection into mice cells from MDA-Fra- 2 clone 1 and 2 and as negative control MDA-pIRES cells were adjusted to $5 \times 10^{6} \mathrm{ml}^{-1}$ medium. $200 \mu \mathrm{l}$ of this suspension were injected subcutaneously between the scapulae of each mouse. Cells from every cell line were injected into groups of 20 animals each. When the primary tumours had reached maximum $20 \%$ of the body weight of the animal at the beginning of the experiment or ulcerated, the mice were terminally narcotized, and then sacrificed by cardiocentesis and cervical dislocation. Right lungs were excised en bloc and prepared for histologic analysis; left lungs were subjected to DNA isolation. Bone marrow was received by flushing the left femora with $1 \mathrm{ml}$ $\mathrm{NaCl}$ 0.9\%. Two hundred microliters of blood and the bone marrow suspension were subjected to DNA isolation. Then primary tumours were removed, weighed, and processed for histologic analysis, RNA isolation, and protein isolation.

\section{Ethical approval and informed consent}

The methodology for carrying out the animal experiments was consistent with the UKCCCR guidelines for the welfare and use of animals in cancer research (Workman et al. 2010) and were carried out in compliance with the appropriate Animal Research: Reporting in vivo Experiment (ARRIVE) guidelines (Percie du Sert et al. 2020). The xenograft experiment was supervised by the animal welfare officer institute and the local licensing authority (Behörde für Soziales, Familie, Gesundheit und Verbraucherschutz, Amt für Lebensmittelsicherheit und Veterinärwesen, Hamburg, Germany) approved the experiment under the Project No. G09/58. All methods were performed in accordance with the relevant guidelines and regulations by the local authorities.

\section{Histology and morphological analysis of spontaneous lung metastases}

One piece of primary tumour, right lung, and bone marrow were fixed in $4 \%$ buffered formalin and processed for wax histology. Five $\mu \mathrm{m}$ sections were cut from primary tumours for immunohistochemistry and hematoxylin and eosin (H.E.) staining. The lungs were fixed en block and subsequently cut into $1 \mathrm{~mm}$-thick slices and embedded in $2 \%$ agar. Afterwards, the lung slices were paraffin-embedded and cut into $5 \mu \mathrm{m}$-thick sections. Ten sections of each paraffin wax block were H.E. stained and metastases were counted at a 200fold magnification using Zeiss Axiophot photomicroscope (Zeiss, Jena, Germany). The total number of lung metastases was determined for all mice using quantitative assessment as described before (Jojovic and Schumacher 2000). Additionally, two series of serial sections out of the middle of each paraffin wax block were preserved for further immunohistological analyses.

\section{DNA extraction and real-time PCR for detection of circulating tumour cells, disseminated tumour cells, and lung metastases}

DNA extraction of $200 \mu \mathrm{l}$ murine blood was performed using the QIAamp DNA Blood Mini Kit (Qiagen, Hilden, Germany), and for DNA isolation of murine bone marrow and lung, the QIAamp DNA Mini Kit (Qiagen, Hilden, Germany) was used, according to manufacturer`s instructions. A serial dilution with tenfold dilution of extracted DNA from $1 \times 10^{6}$ cell culture cells MDA MB231 to one cell was established. Control samples were isolated from mice without injected tumour cells. To quantify human tumour cells by real-time polymerase chain reaction (PCR), established primers specific for human Alusequences were used as described before (Nehmann et al. 2010).

Analyses were performed in triplicates and at least in two independent experiments, for each sample.

\section{RNA isolation and CDNA microarray analysis}

Approximately $50 \mathrm{mg}$ of fresh-frozen primary tumour tissue was crushed in liquid nitrogen. The total RNA was isolated using QIAzol Lysis Reagent (Qiagen, Hilden, Germany) and the miRNeasy Mini Kit (Qiagen, Hilden, Germany), according to manufacturer`s instruction. RNA yield was determined by UV absorbance using NanoDrop 1000 Spectrophotometer (Peqlab, Erlangen, Germany). The RNA quality was assessed by analysis of ribosomal RNA band integrity on an Agilent 2100 Bioanalyzer and RNA 6000 LabChip kit (Agilent Technologies, Palo Alto, CA, USA). The RIN values of RNA samples used for microarray analysis were higher than 7.7. The microarray experiments were performed according to the manufacturer's instructions (TermoFisher Scientific UserGuide $\mathrm{P} / \mathrm{N}$ 703174) and as described in (Khaustova et al. 2017; Kudriaeva et al. 2017). Procedures for cDNA synthesis and labeling were carried out according to the GeneChip WT PLUS Reagent Kit (Applied Biosystems) protocol using $500 \mathrm{ng}$ of total RNA as the starting material. Target DNA fragmentation, labeling, hybridization on Affymetrix Gene Chip Human Transcriptome Array 2.0 microarrays, array washing, staining, and scanning were performed as described in Sakharov et al. (2012). Background correction of the raw microarray data (CEL-files), normalization, and differential expression analysis were carried out using limma v3.13 R package (Ritchie et al. 2015). Functional annotation analysis was performed with DAVID v6.8 (Huang et al. 2009). All CEL-files are available in the Gene Expression Omnibus database (www.ncbi.nlm.nih. gov/geo/) under accession number GSE148089. 


\section{qRT-PCR analysis}

RNA was reverse transcribed to cDNA using $2 \mu \mathrm{g}$ of total RNA as a starting material. Quantitative PCR analysis was carried out using the SYBR Green $5 \times$ qPCRmix-HS SYBR reaction mix (Evrogen, Moscow, Russia). Amplification included 10 min denaturation at $94{ }^{\circ} \mathrm{C}, 40$ cycles 20 s melting at $94{ }^{\circ} \mathrm{C}$ followed by $10 \mathrm{~s}$ annealing at $64{ }^{\circ} \mathrm{C}$ and $15 \mathrm{~s}$ elongation at $72{ }^{\circ} \mathrm{C}$. Primer pairs were designed and characterized as described in Maltseva et al. (2013).

PCR efficiencies of all primer sets were higher than 1.9 and lower than 2.17 (Table 1), except for CTSS (1.79), LGALS1 (1.86), and SRGN (1.88). All RNA samples were analysed in triplicate and averaged. Target genes were normalized to the reference genes PTMA, RPS23, EEF1A1, $A C T B$, and $G A P D H$, and data were processed based on the $\Delta \Delta \mathrm{Ct}$ method (Livak and Schmittgen 2001). Reference gene selection and validation were performed using the approach described in Maltseva et al. (2013).

\section{Protein extraction and Western blot analysis}

For total protein extraction, about $100 \mathrm{mg}$ fresh-frozen primary tumour tissue was crushed in liquid nitrogen and immediately suspended in ice cold self-made RIPA lysis buffer containing a protease inhibitor cocktail (Calbiochem, Darmstadt, Germany). The suspension was stored at
$-20{ }^{\circ} \mathrm{C}$ until usage. Protein content of each sample was determined by BCA protein assay (Pierce BCA Protein Assay kit, Thermo Scientific, Rockford, IL, USA). Western blots were performed as described previously (Schroder et al. 2009). For validation of differentially expressed genes, the following primary and secondary antibodies are specified below; visualization by chemiluminescence reagents (SuperSignal West Pico Chemiluminescent Substrate kit, Thermo Scientific, Rockford, IL, USA) with Hyperfilm ECL films (GE-Healthcare, Freiburg, Germany). Band intensities were quantified by densitometry with GS-800 Calibrated Densitometer (BioRad, München, Germany). The intensities of the specific protein bands were calculated as percentage intensity of the control sample and corrected for equal actin loading.

\section{Commercial antibodies used for Western blot analysis}

\section{Primary antibodies}

B-Actin (RRID: AB_626632; cl C-4;1:500; Santa Cruz, Heidelberg, Germany).

Fra-2 (RRID: AB_2107084; cl Q-20;1:200; Santa Cruz, Heidelberg, Germany).

HCAM (RRID: AB 627,066; CD44; cl F-4; 1:200; Santa Cruz, Heidelberg, Germany).

Table 1 Primer sequences of genes used for qRT-PCR

\begin{tabular}{|c|c|c|c|c|}
\hline Gene symbol & Forward primer $\left(5^{\prime} \rightarrow 3^{\prime}\right)$ & Reverse primer $\left(5^{\prime} \rightarrow 3^{\prime}\right)$ & Efficiency & $\mathrm{SD}(\mathrm{E})$ \\
\hline TSPAN8 & TGAGCGCCACAGGGGAAAGT & CTCCATTGACCAAACCGCAGCA & 1.99 & 0.06 \\
\hline TSPAN6 & TGTACTCCACAGAGAGATGCAGACA & ACGAGAGAGGCAGTAGGCGAGA & 1.95 & 0.16 \\
\hline DSC2 & CTTGCATCAGACCAAGGAGGGAG & AGGCTCATCAGGATCAACCGCA & 1.95 & 0.1 \\
\hline GALNT11 & TGTCATAGACCGCACGCCAG & GCTGTCCAGGAACACAAGGACT & 1.9 & 0.16 \\
\hline ADRM1 & TTGCCATCTGGGGAGTCGCT & AAACGCTTCCACATCGCCCT & 2 & 0.14 \\
\hline BABAM1 & TTCGGACACCAAGGGTCAACTGT & ACGACTCCAGCTTTGGCAGTGA & 1.96 & 0.08 \\
\hline ADGRF5 (GPR116) & ССТCATCССТTCCTGCTGCAAAA & GACTTTCCCCGGCTCTCCGA & 1.94 & 0.09 \\
\hline ESAM & GCTGGAAGTGAGCACAGGGC & GGAGCAATGGCATCCTCCTTGA & 2.05 & 0.06 \\
\hline CTSS & CCCTGGATCACCACTGGCATCT & AGCACCACAAGAACCCATGTCTC & 1.79 & 0.12 \\
\hline MGAT4A & AGCGGCAACCAAGAACATCCTG & CСАССАТTCСТTCTGCAACACCA & 2.04 & 0.09 \\
\hline LGALS1 & ATCATGGCTTGTGGTCTGGT & GCACGAAGCTCTTAGCGTCA & 1.86 & 0.11 \\
\hline MTA2 & AGCAGAGTGCTCCATTCGAC & GGCCACCAGATCTTTGACGA & 2.04 & 0.21 \\
\hline B4GALT6 & ACGTATCTCCCGGAAAACTTCA & AATCCTCGCATATAAGGCAGC & 1.99 & 0.15 \\
\hline CTTN & AGGTGTCCTCTGCCTACCAG & AGCCGCATCCTCATAGACG & 1.95 & 0.09 \\
\hline SRGN & TCTGCAAACTGCCTTGAAGAAAA & CCTGGATTCTCGTCTTTGGAAAA & 1.88 & 0.12 \\
\hline \multicolumn{5}{|l|}{ Reference genes } \\
\hline PTMA & ACCAGCTCCGAAATCACCACCA & AGCAGGGGCGTCTCTTCCAT & 2.17 & 0.08 \\
\hline RPS23 & CCGTAGTCACCGACGAGACCA & TTGGCTGTTTGGCTTCAACTCCT & 2.09 & 0.09 \\
\hline EEF1A1 & CСCTAAAAGCCAAAATGGGAAA & TAGTGGTGGACTTGCCCGAAT & 1.98 & 0.07 \\
\hline ACTB & CTGGAACGGTGAAGGTGACA & AAGGGACTTCCTGTAACAACGCA & 2.03 & 0.08 \\
\hline GAPDH & GAAGGTGAAGGTCGGAGTC & GAAGATGGTGATGGGATTTC & 2.02 & 0.12 \\
\hline
\end{tabular}


ICAM-1 (RRID: AB_627123; cl G-5; 1:250; Santa Cruz, Heidelberg, Germany).

Integrin $\beta 4$ (RRID: AB_626839; G-7; sc-13127; 1:500; Santa Cruz, Heidelberg, Germany).

L1-CAM (cl UJ 127.11; 1:25; obtained from Altevogt Lab, Heidelberg, (Ebeling et al. 1996)).

ALCAM (RRID: AB_868825; ab49496; 1:500; Abcam, Cambridge, United Kingdom).

\section{Secondary antibodies}

HRP goat anti-mouse IgG (RRID: AB_631736; 1:8000; sc-2055; Santa Cruz, Heidelberg, Germany).

HRP goat anti-rabbit IgG (RRID: AB_631748; 1:8000; sc-2054; Santa Cruz, Heidelberg, Germany).

\section{Immunohistochemistry}

Immunohistochemical analyses were performed on paraffinembedded sections of the primary tumour and right lungs. Sections were deparaffinized with xylene and rehydrated in a series of graded ethanol to distilled water. Primary Antibodies, secondary antibodies, and pretreatment are described below. All sections were counterstained with Mayer's hemalum. Photographs were taken using Zeiss Axiophot 2 photomicroscope (Zeiss, Jena, Germany).

Commercial antibodies and pretreatment used for immunohistochemical analysis:

\begin{tabular}{ll}
\hline Antibodies & Pretreatment \\
\hline Fra-2 (RRID: AB_2107084; cl & S1699 (DAKO), microwave \\
Q-20;1:50) & \\
(Santa Cruz, Heidelberg, Ger- & \\
many) & \\
CD44 (RRID: AB_307182; cl & S1699 (DAKO), steamer, $121{ }^{\circ} \mathrm{C}$ \\
L178; 1:100) & \\
(BD_Pharmingen, Heidelberg, & \\
Germany) & \\
ICAM-1 (RRID: AB_627123; cl & S1699 (DAKO), microwave \\
G-5; 1:500) & \\
(Santa Cruz, Heidelberg, Ger- & \\
many) & \\
Integrin $\beta 4$ (RRID: & \\
AB_10866385; cl 439-9B; 1:25) & \\
(Abcam, Cambridge, UK) & \\
LGALS1 (RRID: AB_2136615; & Citrate buffer, water bath, $99{ }^{\circ} \mathrm{C}$ \\
ab25138; 1:400) & \\
(Abcam, Cambridge, UK) & \\
Cortactin (CTTN; RRID: & S1699 (DAKO), microwave \\
AB_2088281; sc11408; 1:50) & \\
(Santa Cruz, Heidelberg, Ger- & \\
many) & \\
Tspan8 (RRID: AB_2678899; & S1699 (DAKO), 125 ${ }^{\circ} \mathrm{C}$ \\
HPA-044337; 1:50) & \\
(Atlas; Merck, Taufkirchen, & \\
Germany) & \\
\hline
\end{tabular}

\begin{tabular}{ll}
\hline Antibodies & Pretreatment \\
\hline L1-CAM (RRID: AB_2133065; & EDTA, microwave \\
UJ127) \\
(Abcam, Cambridge, United \\
Kingdom) \\
Secondary antibodies \\
Anti-mouse IgG (RRID: AB_631736; sc-2005; 1:8000; Santa Cruz, \\
Heidelberg, Germany) \\
Anti-rabbit IgG (RRID: AB_631746; sc-2004; 1:8000; Santa Cruz, \\
Heidelberg, Germany) \\
\hline
\end{tabular}

\section{Statistical analyses}

Data were visualized analysed using Graph Pad Prism 5.0 (GraphPad Software, La Jolla, CA) and SPSS 22.0 software (IBM, Chicago, IL, USA). An ANOVA with post hoc group comparisons model was used to compare tumour weight between control and Fra-2 $\mathrm{cl} 1$ and 2. Due to the explorative nature, no adjustment for multiplicity was applied. For the number of lung metastases and comparison of disseminated tumour cells, a Negative Binomial Generalized Linear Model was applied. The potential confounders tumour weight and time of tumour growth were no independent factors and therefore excluded in all final models. Survival of mice was analysed by Kaplan-Meier survival curves and log-rank tests. All tests were performed at a significance level of $p=0.05$. All $\mathrm{p}$ values are two-sided.

\section{Results}

To analyse the functional role of Fra- 2 in breast cancer cells, we established stable transfectants with overexpression of the transcription factor in the cell line MDA MB231 with the pIRES-Fra-2 vector as previously described (Schroder et al. 2010). Strongly enhanced Fra- 2 expression levels could be confirmed in two single-cell clones (Fra-2 $\mathrm{cl} 1$ and $\mathrm{cl} 2$ ) by western blot analysis (Fig. 1a).

\section{Fra-2 overexpression leads to shortened overall survival and increased number of metastases in a subcutaneous scid xenograft model of human MDA MB231 cells}

To investigate the effects of Fra-2 in vivo, cells of both clones with Fra-2 overexpression as well as control cells were injected subcutaneously into scid mice (Fra-2 cl 1: 22 mice; Fra-2 cl 2: 18 mice; control: 16 mice; total amount of 56 female mice) for a survival experiment. 47 of 56 mice developed primary tumours, particularly $95.5 \%$ of mice inoculated with Fra- $2 \mathrm{cl} 1,83.3 \%$ of mice inoculated with Fra- $2 \mathrm{cl} 2$ as well as $68.8 \%$ of mice which were injected with control cells. At necropsy excised control 


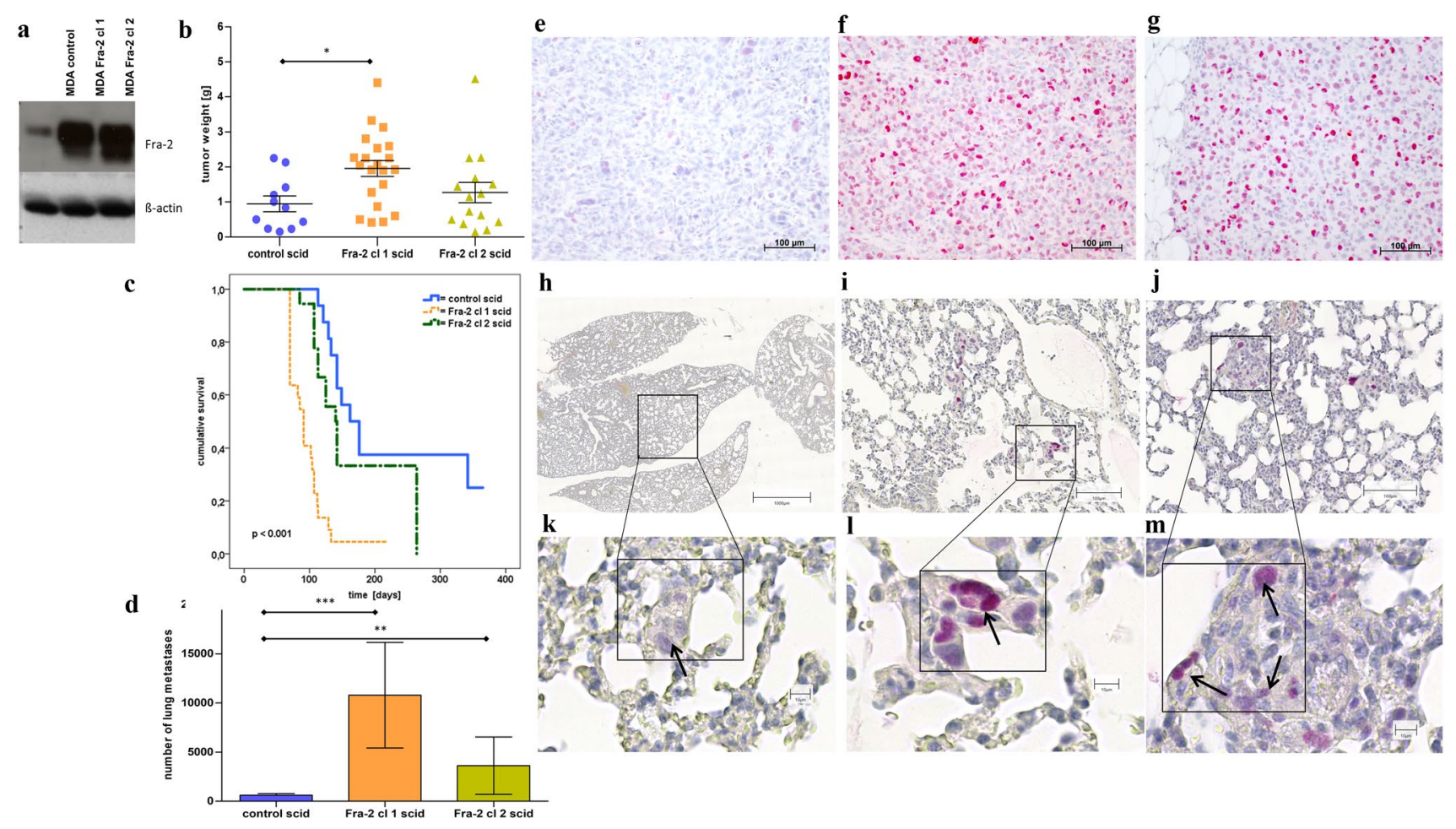

Fig. 1 Effect of Fra-2 overexpression on MDA MB231 cells in vitro and in vivo. a Western Blot analysis of human total cell lysates showing Fra-2 overexpression in clones 1 and 2 relative to the MDA MB231 stably transfected cells harboring the empty pIRES-P vector (MDA control). ß-actin was used as loading control. The Blot is cropped for clarity, with full-length blot presented in Fig S1. b Tumour weight of the resected primary tumours from the scid mice. The tumour weight at the time of death was significantly smaller of the control primary tumours than Fra- $2 \mathrm{cl} 1$ tumours (control mean tumour weight $=0.67 \mathrm{~g}$, Fra- $2 \mathrm{cl} 1$ mean tumour weight $=1.63 \mathrm{~g}$, $p=0.018$; Fra-2 cl 2 mean tumour weight $=0.87 \mathrm{~g}, p=0.513$ ) $(* * * p<0.005 ; * * p<0.01 ; * p<0.05)$. c Kaplan-Meier survival curves of Fra-2 overexpressing human MDA MB231 cells transplanted subcutaneously into scid mice (blue line: scid mice transplanted with the empty vector pIRES = control; deepyellow line: scid

primary tumours were significantly smaller than Fra- $2 \mathrm{cl}$ 1 tumours, whereas the difference to cl 2 tumours did not reach statistical significance (control mean tumour weight $=0.67 \mathrm{~g}$, Fra- $2 \mathrm{cl} 1$ mean tumour weight $=1.63 \mathrm{~g}$, Fra- $2 \mathrm{cl} 2$ mean tumour weight $=0.87 \mathrm{~g}$; control vs Fra- $2 \mathrm{cl}$ $1 p=0.018$; control vs Fra- $2 \mathrm{cl} 2 p=0.513$ ) (Fig. 1b). The time span between injections of the tumour cells until sacrifice will subsequently be referred to as survival time. Survival analysis demonstrated a significantly longer overall survival of the mice injected with control clone compared to mice injected with the Fra- 2 clones 1 and 2 (range $70-342$ days, median survival control $=162$ days, median survival Fra- $2 \mathrm{cl} 1=91$ days, and median survival Fra- $2 \mathrm{cl}$ $2=140$ days, $p<0.001$ ) (Fig. 1c). The presence of microscopically detectable lung metastases was confirmed upon histological examination of the right lung. $94.1 \%$ of mice mice with transplanted Fra- 2 cl 1 cells; lightgreen line: scid mice with transplanted Fra- 2 cl 2 cells $(p<0.001)$. Expression of the transcription factor Fra-2 dramatically decreases survival of the mice after subcutaneous injection of human breast cancer cells overexpressing Fra-2. d Number of microscopically detectable lung metastases in scid mice showing significant differences between Fra- 2 overexpressing and control cells $(* * * p<0.005 ; * * p<0.01 ; * p<0.05)$. Bars represent SEM. e-m Immunohistochemical staining of primary tumours and lung tissues with metastasized cells from scid mice; minimal Fra-2 expression in a primary tumour (e) and in metastasized cells of lung tissue $(\mathbf{h}, \mathbf{k})$ from a scid mouse transplanted with control cells; strong Fra- 2 expression in a primary tumour and in metastasized cells of lung tissue from a scid mouse with transplanted Fra- $2 \mathrm{cl}$ 1 cells $(\mathbf{f}, \mathbf{j}$ and $\mathbf{l})$ and Fra- 2 cl 2 cells $(\mathbf{g}, \mathbf{j}$ and $\mathbf{m})$. Arrow marks metastatic deposit. Scale bar: 100 and $10 \mu \mathrm{m}$

injected with Fra-2 cl 1 developed lung metastases (range from 264 to 93,746 lung metastases, mean $=10,785$ ). We detected lung metastases in $54.5 \%$ of mice injected with Fra- 2 cl 2 cells (range from 140 to 29,744 lung metastases, mean $=3295$, whereas significantly fewer metastases were found in the control group injected with control cells (lung metastases were found in $84.6 \%$ of control mice, range from 89 to 1766 , mean $=576$; control vs Fra- $2 \mathrm{cl} 1$ $p<0.001$, control vs Fra- $2 \mathrm{cl} 2 p=0.007$ ) (Fig. $1 \mathrm{~d}$ ).

To demonstrate that the Fra-2 overexpression still existed in primary tumours grown in scid mice and their metastases, we analysed the Fra- 2 expression by immunohistochemistry. Elevated Fra-2 protein levels could be detected in primary tumours of Fra-2 scid mice (Fig. 1e-g) and could also be observed in corresponding lung metastases (Fig. $1 \mathrm{~h}-\mathrm{m}$ ). 


\section{Microarray analyses of resected tumours and validation of genes with dysregulated expression in scid mouse tumours}

Since Fra-2 overexpression also resulted in an increased number of metastases and reduced overall survival in scid mice, cDNA arrays with mRNA isolated from xenograft tumour tissue were performed and analysed (three tumours per group). Genes that were at least twofold increased or decreased compared with the respective control were further considered to be significantly dysregulated (adjusted $p$ value below 0.05). According to these criteria, the expression of 63 genes were altered in scid primary tumours of both clones at the same time (upregulated: 27 genes, downregulated: 36 genes). The further enrichment analysis showed that alterations of extracellular matrix and cell surface were the most prominent function attributed to these genes followed by "signal peptide" and "calcium ion binding". The analysis of two clones separately revealed 65 (control vs Fra- $2 \mathrm{cl} 1$ ) and 33 (control vs Fra-2 $\mathrm{cl}$ 2) genes, respectively, that were upregulated and 47 (control vs Fra-2 cl 1) and 45 (control vs Fra-2 cl 2) genes, respectively, that were downregulated in scid primary tumours.

The focus of our analyses was directed on genes that are commonly associated with altered adhesion behavior of tumour cells and/or carrying selectin-binding sites on the cell surface. In the analysed groups, no concordant genes were identified in the resected tumours of injected Fra- $2 \mathrm{cl} 1$ and Fra- 2 cl 2 cells, but prospective candidates with corresponding characteristics were found among the upregulated genes in both Fra- 2 groups. In particular, genes such as L1-CAM, ITGB4, DSC2 (Desmocollin 2), TSPAN8 (Tetraspanin 8), or GPR116 have been upregulated and MAN1A1 or MMP1 have been downregulated compared to the control (Table 2). Using qRT-PCR, we could validate Fra-2-mediated upregulation for AGRF5 (GPR116), TSPAN8, DSC2, TSPAN6, and MGAT4A (Table 3). We chose L1-CAM, ICAM-1, and CD44-based on earlier results (Schroder et al. 2010) - and ITGB4 and TSPAN8 to exemplarily verify the microarray results on protein level. In a western blot analysis, we were able to confirm a different regulation of L1-CAM and CD44 in both clones compared to the respective control samples using protein lysates obtained from tumours of the resected mice (Fig. 2a) However, we could only detect a higher expression of ICAM-1 in Fra-2 cl 2 (Fig. 2a), but by immunohistochemical staining of sections from primary tumours and metastases of lung tissue, we could validate expression differences of ICAM-1 between both Fra-2 clones compared to the control (Fig. 3b). We also found a visibly stronger expression of L1-CAM, CD44, and ITGB4 in the scid mice primary tumours and lung metastases injected with Fra-2 overexpressing cells by immunohistochemical staining (Fig. 3a,c,d). For TSPAN8, however, we could only detect a positive immunoreactivity in the lungs (Fig. 3e).

Table 2 is included in a separate file.

\section{E- and P-selectin deficiency in mice leads to longer overall survival}

To examine whether E- and P-selectin and tumour cell interactions took part in malignant progression in vivo, the transfected cells were injected subcutaneously in a total amount of $53 \mathrm{E}$ - and P-selectin double knock-out scid mice (select), 19 of them with Fra- 2 cl 1 cells, 18 with Fra- 2 cl 2 cells, and 16 with control cells. Primary tumour growth was observed in 38 of 53 mice (71.7\%), more precisely in 18 of 19 mice injected with Fra- 2 cl 1 cells (94.7\%) and in 13 of 18 mice injected with Fra- 2 cl 2 cells (72.2\%), whereas only 7 of $16(43.8 \%)$ of the control injected mice developed primary tumours after a time period of 300 days in the survival experiment. There was no significant difference between the tumour weights of controls and both Fra- 2 clones in the select mice (control mean tumour weight $=1.17 \mathrm{~g}$, Fra- $2 \mathrm{cl}$ 1 mean tumour weight $=1.43 \mathrm{~g}$, Fra- $2 \mathrm{cl} 2$ mean tumour weight $=0.61 \mathrm{~g}$; control vs Fra- $2 \mathrm{cl} 1 p=0.656$; control vs Fra-2 $\mathrm{cl} 1 p=0.165$ ) (Fig. 2b), although the termination criteria between the different groups were applied in the same way. However, survival analysis demonstrated a significantly longer overall survival of the select mice injected with control cells compared with select mice injected with the Fra-2 cls 1 and 2 cells, similar to the results in scid mice (range 64-321 days, median survival Fra- $2 \mathrm{cl} 1=87$ days, median survival Fra $2 \mathrm{cl} 2=183$ days, $p<0.001$ ) (Fig. 2 c).

Spontaneous lung metastases were histologically detected in 50\% of Fra- 2 control cells in select mice (range from 560 to 2786 lung metastases, mean $=620$ ). In comparison, lung metastases were found in $100 \%$ of select mice injected with Fra-2 cl 1 cells (range from 1591 to 107,184 lung metastases, mean $=15,074 ; p<0.001$ ), while in $66.7 \%$ of select mice injected with Fra- 2 cl 2 cells, microscopically detectable lung metastases were found (range from 414 to 2688 lung metastases, mean $=1115 ; p=0.155$ ) (Fig. 2d).

On comparison of the two experiments to estimate the survival function between the scid and select mice, a significantly shorter overall survival of scid $(n=56)$ mice versus select $(n=53)$ mice could be observed (median survival scid $=125$ days, median survival select $=154$ days, $p=0.034$ ) (Fig. 2e). Due to the median survival advantage of almost 29 days, we assumed that the selectin status of the immunodeficient mice did directly influence overall survival.

Remarkably quantitative real-time Alu-PCR of bone marrow did show significantly reduced numbers of disseminated tumour cells in the select mice compared to the scid mice (mean of DTCs scid mice $=0.2430$ cells $/ 60 \mathrm{ng}$ template DNA, mean of DTCs select mice $=0.0360$ cells $/ 60 \mathrm{ng}$ 
Table 2 Selection of genes, which were deregulated by Fra- 2 overexpression in scid mice

\begin{tabular}{|c|c|c|c|c|c|c|}
\hline Gene symbol & Gene title & Fold change & $p$ value & Validation method & Fold Change & $p$ value \\
\hline & $\begin{array}{l}\text { Control scid vs Fra- } 2 \text { cl } 1 \text { scid tumour } \\
\text { Increase }\end{array}$ & & & & \multicolumn{2}{|c|}{$\begin{array}{l}\text { Control scid vs Fra- } 2 \mathrm{cl} \\
2 \text { scid tumour }\end{array}$} \\
\hline GPR116 & G protein-coupled receptor 116 & 2.0 & 0.00208763 & qRT-PCR & 2.6 & 0.02192253 \\
\hline TSPAN8 & Tetraspanin 8 & 2.1 & 0.002 & qRT-PCR & 1.5 & 0.0785871 \\
\hline ITGB4 & Integrin, beta 4 & 1.5 & 0.00033547 & IHC & 1.1 & 0.72106998 \\
\hline$D S C 2$ & Desmocollin 2 & 2.1 & 0.00006535 & qRT-PCR & 2.2 & 0.05738855 \\
\hline$L 1-C A M$ & L1 cell adhesion molecule & 1.4 & 0.01070848 & WB/IHC & 2.0 & 0.21294704 \\
\hline \multirow[t]{2}{*}{ ITGA10 } & Integrin, alpha 10 ; integrin alpha-10-like & 1.5 & 0.0015988 & $\mathrm{n} / \mathrm{a}$ & 1.2 & 0.62095434 \\
\hline & $\begin{array}{l}\text { Control scid vs Fra- } 2 \text { cl } 1 \text { scid tumour } \\
\text { Decrease }\end{array}$ & & & & \multicolumn{2}{|c|}{$\begin{array}{l}\text { Control scid vs Fra-2 cl } \\
2 \text { scid tumour }\end{array}$} \\
\hline MAN1A1 & Mannosidase, alpha, class 1A, member 1 & -5.4 & 0.00019338 & $\mathrm{n} / \mathrm{a}$ & -2.4 & 0.01352611 \\
\hline$S R P X$ & Sushi-repeat containing protein, $\mathrm{X}$-linked & -2.0 & 0.0052303 & $\mathrm{n} / \mathrm{a}$ & -1.7 & 0.11159797 \\
\hline$T N C$ & Tenascin $\mathrm{C}$ & -2.2 & 0.00055037 & $\mathrm{n} / \mathrm{a}$ & -1.4 & 0.41584994 \\
\hline CTSL1 & Cathepsin L1 & -2.1 & 0.00008895 & $\mathrm{n} / \mathrm{a}$ & -1.6 & 0.06486182 \\
\hline CXCR4 & Chemokine (C-X-C motif) receptor 4 & -2.1 & 0.00030803 & $\mathrm{n} / \mathrm{a}$ & -1.8 & 0.01434181 \\
\hline MAN2A1 & Mannosidase, alpha, class 2A, member 1 & -1.5 & 0.01363244 & $\mathrm{n} / \mathrm{a}$ & -1.2 & 0.1078938 \\
\hline ITGB8 & Integrin, beta 8 & -1.7 & 0.00027035 & $\mathrm{n} / \mathrm{a}$ & -1.7 & 0.00171451 \\
\hline \multirow[t]{2}{*}{$A L C A M$} & Activated leukocyte cell adhesion molecule & -1.7 & 0.00766435 & IHC not shown & -1.3 & 0.09498473 \\
\hline & $\begin{array}{l}\text { Control scid vs Fra- } 2 \text { cl } 2 \text { scid tumour } \\
\text { Increase }\end{array}$ & & & & \multicolumn{2}{|c|}{$\begin{array}{l}\text { Control scid vs Fra-2 cl } \\
1 \text { scid tumour }\end{array}$} \\
\hline CTSS & Cathepsin S & 2.1 & 0.00068139 & qRT-PCR & 1.3 & 0.04249498 \\
\hline TSPAN6 & Tetraspanin 6 & 1.6 & 0.00198598 & qRT-PCR & 1.5 & 0.03193598 \\
\hline \multirow[t]{2}{*}{ MGAT4A } & $\begin{array}{l}\text { Mannosyl (alpha-1,3-)-glycoprotein beta-1,4- } \mathrm{N} \text { - } \\
\text { acetylglucosaminyltransferase, isozyme A }\end{array}$ & 1.8 & 0.00238961 & qRT_PCR & 1.2 & 0.10289642 \\
\hline & $\begin{array}{l}\text { Control scid vs Fra- } 2 \text { cl } 2 \text { scid tumour } \\
\text { Decrease }\end{array}$ & & & & \multicolumn{2}{|c|}{$\begin{array}{l}\text { Control scid vs Fra- } 2 \text { cl } \\
1 \text { scid tumour }\end{array}$} \\
\hline$M M P 1$ & Matrix metallopeptidase 1 & -4.3 & 0.0010812 & IHC not shown & -2.4 & 0.00400168 \\
\hline ST8SIA4 & $\begin{array}{l}\text { ST8 alpha- } N \text {-acetyl-neuraminide alpha-2,8-sia- } \\
\text { lyltransferase } 4\end{array}$ & -1.7 & 0.01635993 & qRT_PCR not shown & -1.5 & 0.03548038 \\
\hline B4GALT5 & $\begin{array}{l}\text { UDP-Gal:betaGlcNAc beta-1,4-galactosyltrans- } \\
\text { ferase, polypeptide } 5\end{array}$ & -1.5 & 0.03930351 & qRT_PCR not shown & -1.2 & 0.16447326 \\
\hline ITGB8 & Integrin, beta 8 & -1.7 & 0.00171451 & $\mathrm{n} / \mathrm{a}$ & -1.7 & 0.00027035 \\
\hline CSGALNACT2 & $\begin{array}{l}\text { Chondroitin sulfate } N \text {-acetylgalactosaminyl- } \\
\text { transferase } 2 \mathrm{~L}\end{array}$ & -1.5 & 0.00291929 & $\mathrm{n} / \mathrm{a}$ & -1.4 & 0.01102847 \\
\hline
\end{tabular}

The entire list of data is deposited in the Gene Expression Omnibus database (see Data availability)

Table 3 Validation of microarray results by qRT-PCR of selected genes

\begin{tabular}{|c|c|c|c|c|c|c|}
\hline \multirow[t]{2}{*}{ Gene symbol } & \multicolumn{2}{|c|}{ Fra-2 cl2 vs pIRES } & \multicolumn{2}{|c|}{ Fra-2 cl8 vs pIRES } & \multicolumn{2}{|c|}{$\begin{array}{l}\text { Fra-2 (cl2+cl8) vs } \\
\text { pIRES }\end{array}$} \\
\hline & $\mathrm{FC}$ & $p$ value & $\mathrm{FC}$ & $p$ value & $\mathrm{FC}$ & $p$ value \\
\hline AGRF5 (GPR116) & 5.2 & $<0.00001$ & 13.0 & 0.009 & 9.1 & 0.014 \\
\hline TSPAN8 & 7.4 & 0.00014 & 2.8 & 0.009 & 5.1 & 0.002 \\
\hline DSC2 & 3.1 & $<0.00001$ & 1.8 & 0.16 & 2.5 & 0.015 \\
\hline CTSS & 1.2 & 0.18 & 2.1 & 0.007 & 1.7 & 0.033 \\
\hline TSPAN6 & 1.6 & 0.0008 & 3.5 & 0.000016 & 2.5 & 0.0014 \\
\hline MGAT4A & 2.0 & 0.00001 & 8.3 & 0.003 & 5.2 & 0.019 \\
\hline
\end{tabular}

Data in italics are not statistically significant 
a


$\overline{0} \frac{0}{0}$

造

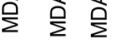

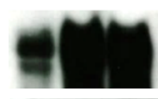

control scid

Protein lysate of primary tumours

Fra-2 cl 1 scid $\quad$ Fra-2 cl 2 scid
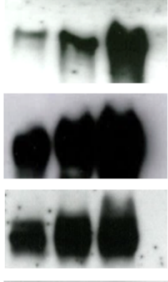

d
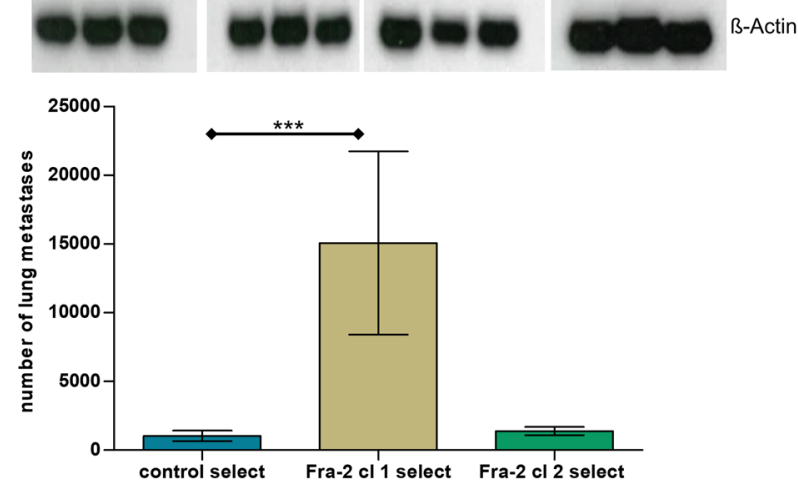

e

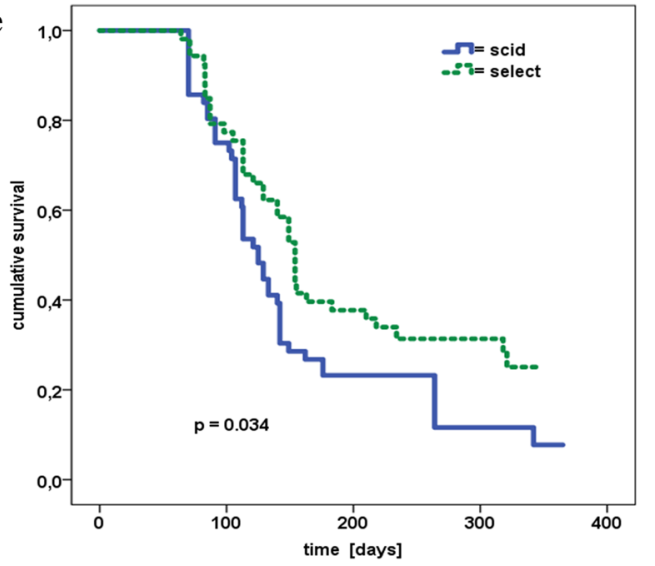

Fig. 2 a Western blot analysis; cell lysates of the transfected MDA MB231 cells (first 3 rows) and protein lysates of the resected scid mouse primary tumours of control (second 3 rows), Fra- $2 \mathrm{cl} 1$ and 2 cells with staining of L1-CAM, ICAM-1, CD44; (loading control $B$-actin). Original non-cropped images of the scanned immunoblot membranes are shown in Figs S2 (a-d), respectively. b Tumour weight of the resected primary tumours from the select mice. No significant difference between the tumour weights of control and both Fra-2 clones in the select mice (mean tumour weight: control $=1.17 \mathrm{~g}$, Fra-2 cl $1=1.43 \mathrm{~g}, p=0.656$; Fra-2 $\mathrm{cl} 2=0.61 \mathrm{~g}$, $p=0.165)(* * * p<0.005 ; * * p<0.01 ; * p<0.05)$. c Kaplan-Meier survival curves of Fra- 2 overexpressing human MDA MB231 cells transplanted subcutaneously into select mice revealed significantly longer overall survival of the select mice injected with control cells compared with select mice injected with the Fra- 2 cls 1 and 2 cells, simi- b

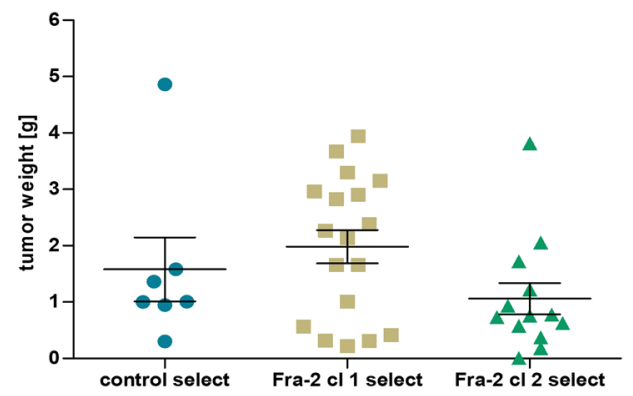

c
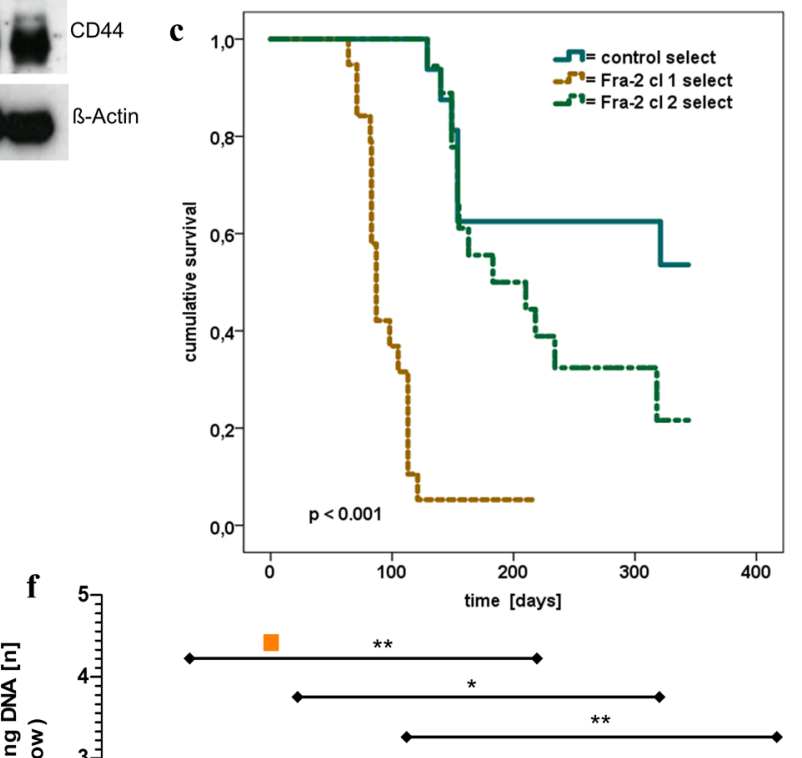

녈

है

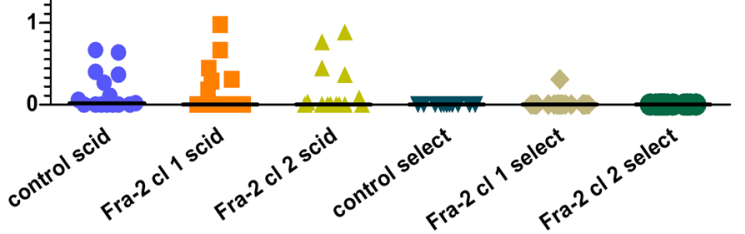

lar to the results in scid mice (range 64,321 days, median survival: Fra- $2 \mathrm{cl} 1=87$ days, and Fra $2 \mathrm{cl} 2=183$ days, $p<0.001$ ) (oceanblue line: select mice with the empty vector pIRES $=$ control; yellowocher dotted line: select mice with Fra- 2 cl 1 cells; mossgreen dashed line: select mice with Fra- 2 cl 2 cells $(p<0.001)$. d Number of microscopically detectable lung metastases in select mice; the difference between control and Fra- $2 \mathrm{cl} 1$ is clearly significant $(p<0.005)$, respectively $(* * * p<0.005 ; * * p<0.01 ; * p<0.05)$. e Remarkably, comparing by Kaplan-Meier analysis, survival curves of scid (blue continuous line) and select mice (green dotted line) showing a significantly better prognosis for the select mice (median survival: scid $=125$ days, select $=154$ days, $p=0.034$ ). $\mathbf{f}$ DTCs in the animals' bone marrow showing a significantly reduced number of disseminated tumour cells in the select mice compared to the scid mice $(p=0.014)\left({ }^{* * *} p<0.005 ; *^{*} p<0.01 ; * p<0.05\right)$. Bars represent SEM 


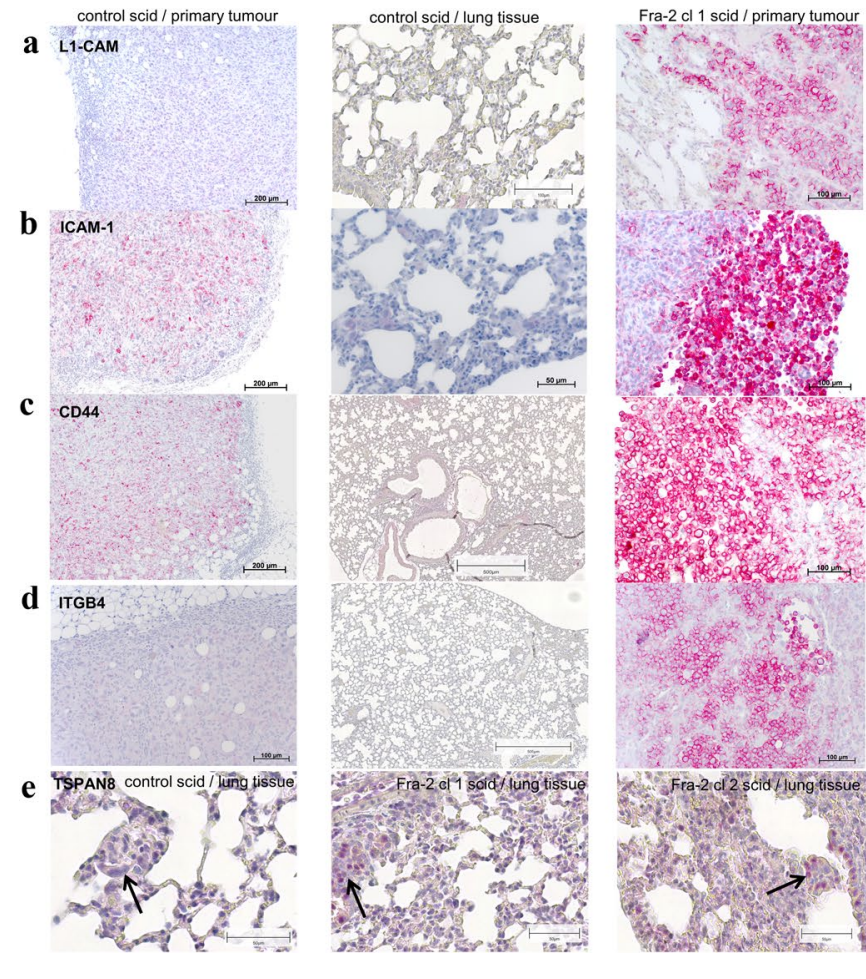

Fig. 3 Immunohistochemistry of primary tumours engrafted in scid mice and their spontaneous metastases in the lung tissue. a-d IHC staining of representative paraffin-embedded primary tumour tissue and lung tissue with metastasized cells grown in scid mice showing a higher immunoreactivity of L1-CAM, ICAM-1, CD44, and ITGB4

template DNA, $p=0.014$ ) (Fig. 2f). Almost no detectable human cells were found in the select mice except in one injected with Fra- 2 cl 1 cells $(0.31$ cells/ 60 ng template DNA) and one injected with Fra-2 cl 2 cells ( 1.56 cells/60 ng template DNA) (4.3\% of mice) compared to the scid mice, where in $47.1 \%$ of mice, human DNA was detected in the bone marrow. Taken together, our data suggest an essential effect of the selectins on cell engraftment in the bone marrow and lungs.

\section{Microarray analyses of resected tumours and validation of genes with dysregulated expression in select mice tumours}

As Fra-2 overexpression with Fra- 2 cl 1 cells transplanted into select mice also led to an increased metastatic load and significantly reduced survival in the select mice; again, microarray analyses were performed as described before.

According to our criteria, 369 genes were differentially expressed in select primary tumours of both clones at the same time (upregulated: 173 genes, downregulated: 196 genes). The further enrichment analysis showed that alterations of "membrane", "extracellular matrix", "extracellular exosome", "cell adhesion", and "focal adhesion" were the
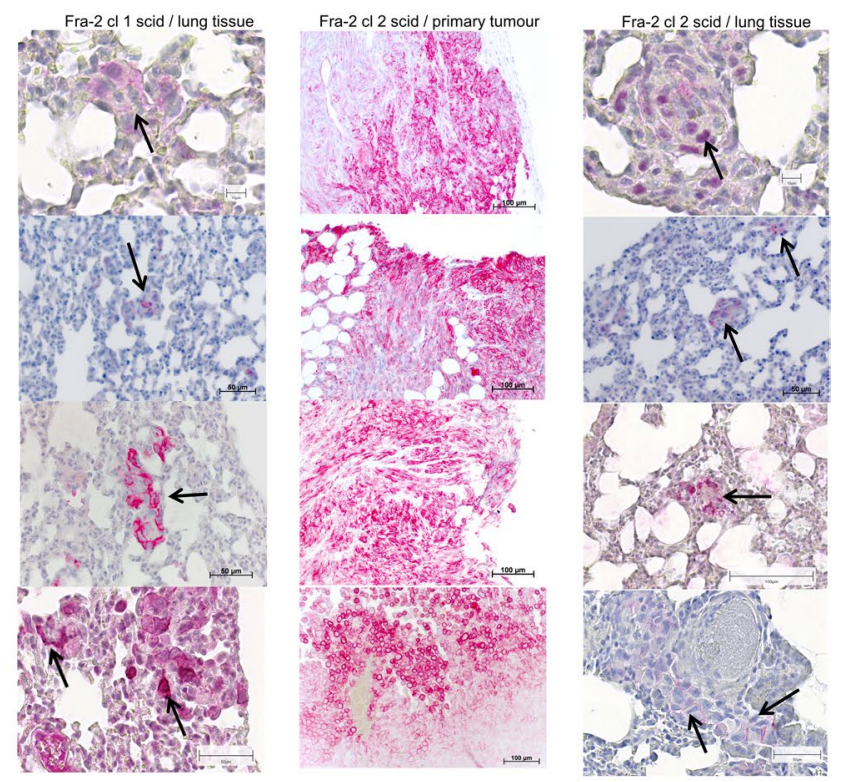

in the tumour cells. Scale bar: 200 and $50 \mu \mathrm{m}$. e Images of paraffinembedded lung sections of scid mice display an immunoreactivity of TSPAN8 within the metastasized cells. This could indicate that these genes are essential for the tumour cells during the emigration process. Arrows label metastasized cells in the lungs. Scale bar: $100 \mu \mathrm{m}$

most prominent among the affected molecular functions' groups. The analysis of two clones separately revealed 146 (control vs Fra-2 cl 1) and 457 (control vs Fra-2 cl 2) upregulated genes, respectively, and 258 (control vs Fra-2 cl 1) and 328 (control vs Fra-2 $\mathrm{cl}$ 2) downregulated genes, respectively, in select mouse tumours, respectively.

Again, we focused on genes that could putatively play a role in the adhesion of tumour cells to endothelial cells as the gene product can interact with selectins. In both groups (Fra-2 $\mathrm{cl} 1$ and $\mathrm{cl} 2$ ), some interesting genes could be identified, e.g., in the Fra- $2 \mathrm{cl} 1$ primary tumours $L G A L S 1$, $A D R M 1$, and $C T T N$, which were upregulated and $L U M$ (Lumican), MAN1A1, and SPARC, which were significantly downregulated. For Fra- $2 \mathrm{cl} 2$ primary tumours, genes such as $S R G N$ (Serglycin) and ESAM were upregulated, while CD99 and SELPLG (selectin P ligand) were downregulated (Table 4).

In addition, comparing Fra- $2 \mathrm{cl} 1$ and $\mathrm{cl} 2$ primary tumours in the select group, we found matched genes that were equally regulated by Fra- 2 in both clones. CTTN was upregulated; meanwhile, $M M P 2, Z E B 2$, and SELPLG were downregulated in both clones. Using qRT-PCR, we could validate Fra-2 mediated upregulation for $A D R M 1$, GALNT11, BABAM1, ESAM, LGALS1, and CTTN (Table 5). 
Table 4 Selection of genes, which were deregulated by Fra- 2 overexpression in select mice

\begin{tabular}{|c|c|c|c|c|c|c|}
\hline Gene symbol & Gene title & Fold Change & ANOVA $p$ value & Validation method & Fold change & ANOVA $p$ value \\
\hline & \multicolumn{4}{|l|}{$\begin{array}{l}\text { Control select vs Fra- } 2 \mathrm{cl} 1 \text { select tumour } \\
\text { Increase }\end{array}$} & \multicolumn{2}{|c|}{$\begin{array}{l}\text { Control select vs Fra-2 cl } 2 \\
\text { select tumour }\end{array}$} \\
\hline$L G A L S 1$ & Lectin, galactoside-binding, soluble, 1 & 2.2 & 0.00431535 & qRT-PCR/IHC & 1.7 & 0.01798879 \\
\hline MTA2 & $\begin{array}{l}\text { Metastasis associated } 1 \text { family, member } \\
2\end{array}$ & 1.8 & 0.00647685 & qRT-PCR/IHC & 1.5 & 0.05890602 \\
\hline B4GALT6 & $\begin{array}{l}\text { UDP-Gal:betaGlcNAc beta-1,4-galacto- } \\
\text { syltransferase, polypeptide } 6\end{array}$ & 1.4 & 0.2966968 & qRT-PCR & 1.7 & 0.04574728 \\
\hline$A D R M 1$ & Adhesion regulating molecule 1 & 1.5 & 0.03346412 & qRT-PCR & 1.5 & 0.09002897 \\
\hline$C T T N$ & Cortactin & 1.5 & 0.0072002 & qRT-PCR/WB & 1.6 & 0.0200769 \\
\hline GALNT11 & $\begin{array}{l}\text { UDP- } N \text {-acetyl-alpha-D- } \\
\text { galactosamine:polypeptide } \\
N \text {-acetylgalactosaminyltransferase } 11 \\
\text { (GalNAc-T11) }\end{array}$ & 1.3 & 0.11281676 & qRT-PCR & 1.0 & 0.89901574 \\
\hline \multirow[t]{2}{*}{$B A B A M 1$} & $\begin{array}{l}\text { BRISC and BRCA1 A complex mem- } \\
\text { ber } 1\end{array}$ & 1.3 & 0.04428669 & qRT-PCR & 1.1 & 0.52440179 \\
\hline & \multicolumn{4}{|l|}{$\begin{array}{l}\text { Control select vs Fra- } 2 \text { cl } 1 \text { select tumour } \\
\text { Decrease }\end{array}$} & \multicolumn{2}{|c|}{$\begin{array}{l}\text { Control select vs Fra- } 2 \mathrm{cl} 2 \\
\text { select tumour }\end{array}$} \\
\hline CTSO & Cathepsin O & -3.6 & 0.00213909 & $\mathrm{n} / \mathrm{a}$ & -4.2 & 0.00607428 \\
\hline MGAT5 & $\begin{array}{l}\text { Mannosyl (alpha-1,6-)-glycoprotein } \\
\text { beta-1,6- } N \text {-acetyl-glucosaminyltrans- } \\
\text { ferase }\end{array}$ & -3.2 & $9.65 \mathrm{E}-05$ & $\mathrm{n} / \mathrm{a}$ & -1.6 & 0.04360072 \\
\hline MAN1A1 & $\begin{array}{l}\text { Mannosidase, alpha, class } 1 \mathrm{~A}, \text { member } \\
1\end{array}$ & -4.7 & 0.00842035 & $\mathrm{n} / \mathrm{a}$ & -3.8 & 0.012972 \\
\hline$M M P 2$ & Matrix metallopeptidase 2 & -1.8 & 0.20919243 & IHC not shown & -2.7 & 0.00117561 \\
\hline CTSL1 & Cathepsin L1 & -2.1 & 0.01190166 & $\mathrm{n} / \mathrm{a}$ & -1.8 & 0.01014816 \\
\hline$L U M$ & Lumican & -2.4 & 0.05014903 & $\mathrm{n} / \mathrm{a}$ & -1.8 & 0.2663245 \\
\hline$P D G F C$ & Platelet-derived growth factor $\mathrm{C}$ & -2.0 & 0.00712603 & $\mathrm{n} / \mathrm{a}$ & -2.7 & 0.04867148 \\
\hline$M A N B A$ & Mannosidase, beta A & -2.3 & 0.00057998 & $\mathrm{n} / \mathrm{a}$ & -3.0 & 0.0012044 \\
\hline LDOC1 & $\begin{array}{l}\text { Leucine zipper, downregulated in } \\
\text { cancer } 1\end{array}$ & -1.2 & 0.46218117 & $\mathrm{n} / \mathrm{a}$ & -1.4 & 0.2096031 \\
\hline$S P A R C$ & $\begin{array}{l}\text { Secreted protein, acidic, cysteine-rich } \\
\text { (osteonectin) }\end{array}$ & -1.5 & 0.0091225 & $\mathrm{n} / \mathrm{a}$ & -1.8 & 0.15875616 \\
\hline GALNT1 & $\begin{array}{l}\text { UDP- } N \text {-acetyl-alpha-D- } \\
\text { galactosamine:polypeptide } N \text {-acetyl- } \\
\text { galactosaminyltransferase } 1 \text { (GalNAc- } \\
\text { T1) }\end{array}$ & -1.5 & 0.03394277 & $\mathrm{n} / \mathrm{a}$ & -2.0 & 0.15452444 \\
\hline$Z E B 2$ & ZEB2 & -1.7 & 0.00178154 & $\mathrm{n} / \mathrm{a}$ & -1.7 & 0.01131962 \\
\hline GALNT7 & $\begin{array}{l}\text { UDP-N-acetyl-alpha-D- } \\
\text { galactosamine:polypeptide } N \text {-acetyl- } \\
\text { galactosaminyltransferase } 7 \text { (GalNAc- } \\
\text { T7) }\end{array}$ & -1.5 & 0.06684931 & $\mathrm{n} / \mathrm{a}$ & -1.4 & 0.30001461 \\
\hline HAPLN3 & $\begin{array}{l}\text { Hyaluronan and proteoglycan link } \\
\text { protein } 3\end{array}$ & -1.3 & 0.08629049 & $\mathrm{n} / \mathrm{a}$ & -1.5 & 0.05355493 \\
\hline SELPLG & Selectin P ligand & -1.5 & 0.01487063 & IHC not shown & -1.6 & 0.04884421 \\
\hline ST6GALNAC5 & $\begin{array}{l}\text { ST6 (alpha- } N \text {-acetyl-neuraminyl- } \\
\text { 2,3-beta-galactosyl-1,3)- } N \text {-acetylga- } \\
\text { lactosaminide alpha-2,6-sialyltrans- } \\
\text { ferase } 5\end{array}$ & -1.2 & 0.08559022 & $\mathrm{n} / \mathrm{a}$ & -1.1 & 0.50882932 \\
\hline \multirow[t]{2}{*}{$\begin{array}{l}\text { Gene } \\
\text { symbol }\end{array}$} & Gene title & Fold change & $p$ value & Validation method & Fold Change & $p$ value \\
\hline & \multicolumn{3}{|l|}{$\begin{array}{l}\text { Control select vs Fra- } 2 \text { cl } 2 \text { select tumour } \\
\text { Increase }\end{array}$} & & \multicolumn{2}{|c|}{$\begin{array}{l}\text { Control select vs Fra-2 cl } 1 \\
\text { select tumour }\end{array}$} \\
\hline SRGN & Serglycin & 9.9 & 0.0000102 & qRT-PCR & 2.1 & 0.04986751 \\
\hline$C T T N$ & Cortactin & 1.6 & 0.0200769 & qRT-PCR/IHC & 1.5 & 0.0072002 \\
\hline
\end{tabular}


Table 4 (continued)

\begin{tabular}{|c|c|c|c|c|c|c|}
\hline $\begin{array}{l}\text { Gene } \\
\text { symbol }\end{array}$ & Gene title & Fold change & $p$ value & Validation method & Fold Change & $p$ value \\
\hline \multirow[t]{2}{*}{$E S A M$} & Endothelial cell adhesion molecule & 1.4 & 0.0901989 & qRT-PCR/IHC & 1.5 & 0.01365101 \\
\hline & $\begin{array}{l}\text { Control select vs Fra- } 2 \text { cl } 2 \text { select tumour } \\
\text { Decrease }\end{array}$ & & & & \multicolumn{2}{|c|}{$\begin{array}{l}\text { Control select vs Fra-2 cl } 1 \\
\text { select tumour }\end{array}$} \\
\hline$C D O N$ & Cell adhesion associated, oncogene regulated & -3.4 & 0.00022592 & $\mathrm{n} / \mathrm{a}$ & -1.6 & 0.24959834 \\
\hline$M M P 2$ & Matrix metallopeptidase 2 & -2.7 & 0.00117561 & IHC not shown & -1.8 & 0.20919243 \\
\hline CD99 & CD99 molecule & -3.2 & 0.00014262 & $\mathrm{n} / \mathrm{a}$ & -1.3 & 0.02444132 \\
\hline$M A N B A$ & Mannosidase, beta A & -3.0 & 0.0012044 & $\mathrm{n} / \mathrm{a}$ & -2.3 & 0.00057998 \\
\hline PLAUR & Plasminogen activator, urokinase receptor & -2.7 & 0.00067957 & $\mathrm{n} / \mathrm{a}$ & -1.8 & 0.17676286 \\
\hline$C T S B$ & Cathepsin B & -2.1 & 0.0021906 & $\mathrm{n} / \mathrm{a}$ & -1.4 & 0.04344705 \\
\hline$D S G 2$ & Desmoglein 2 & -2.1 & 0.00965429 & $\mathrm{n} / \mathrm{a}$ & -1.4 & 0.03179364 \\
\hline$O G T$ & $\begin{array}{l}O \text {-linked } N \text {-acetylglucosamine (GlcNAc) } \\
\text { transferase }\end{array}$ & -2.2 & 0.00615686 & $\mathrm{n} / \mathrm{a}$ & -1.8 & 0.00149708 \\
\hline SMAD4 & SMAD family member 4 & -2.0 & 0.00733559 & $\mathrm{n} / \mathrm{a}$ & -1.2 & 0.09374416 \\
\hline$S M A D 2$ & SMAD family member $2 \mathrm{~L}$ & -2.0 & 0.01306913 & $\mathrm{n} / \mathrm{a}$ & -1.3 & 0.05717904 \\
\hline CTSL1 & Cathepsin L1 & -1.8 & 0.01014816 & $\mathrm{n} / \mathrm{a}$ & -2.1 & 0.01190166 \\
\hline$G L B 1$ & Galactosidase, beta-1 & -1.7 & 0.01506378 & $\mathrm{n} / \mathrm{a}$ & -1.3 & 0.07456839 \\
\hline ST8SIA4 & $\begin{array}{l}\text { ST8 alpha- } N \text {-acetyl-neuraminide alpha- } \\
\text { 2,8-sialyltransferase } 4\end{array}$ & -1.9 & 0.00717723 & $\mathrm{n} / \mathrm{a}$ & -1.2 & 0.67029747 \\
\hline GJB2 & Gap junction protein, beta 2 & -2.3 & 0.00184347 & $\mathrm{n} / \mathrm{a}$ & -1.2 & 0.44925495 \\
\hline SELPLG & Selectin P ligand & -1.6 & 0.04884421 & IHC not shown & -1.5 & 0.01487063 \\
\hline$M A N 2 B 2$ & Mannosidase, alpha, class 2B, member 2 & -1.6 & 0.02517537 & $\mathrm{n} / \mathrm{a}$ & -1.1 & 0.40962084 \\
\hline ZEB2 & ZEB2 & -1.7 & 0.01131962 & $\mathrm{n} / \mathrm{a}$ & -1.7 & 0.00178154 \\
\hline$S M A G P$ & Small cell adhesion glycoprotein & -1.5 & 0.04141548 & $\mathrm{n} / \mathrm{a}$ & -1.0 & 0.87646386 \\
\hline$J U N B$ & Jun B proto-oncogene & -1.5 & 0.03292006 & IHC not shown & -1.0 & 0.93067704 \\
\hline
\end{tabular}

The entire list of data is deposited in the Gene Expression Omnibus database (see Data availability)

Table 5 Validation of microarray results by qRT-PCR of selected genes

\begin{tabular}{|c|c|c|c|c|c|c|}
\hline \multirow[t]{2}{*}{ Gene symbol } & \multicolumn{2}{|c|}{ Fra- 2 cl 2 vs pIRES } & \multicolumn{2}{|c|}{ Fra- 2 c18 vs pIRES } & \multicolumn{2}{|c|}{$\begin{array}{l}\text { Fra-2 }(\mathrm{cl} 2+\mathrm{cl} 8) \text { vs } \\
\text { pIRES }\end{array}$} \\
\hline & $\mathrm{FC}$ & $p$ value & $\mathrm{FC}$ & $p$ value & $\mathrm{FC}$ & $p$ value \\
\hline ADRM1 & 0.91 & 0.24 & 0.78 & 0.11 & 0.85 & 0.15 \\
\hline GALNT11 & 4.23 & $<0.00001$ & 1.38 & 0.049 & 2.81 & 0.028 \\
\hline BABAM1 & 1.48 & 0.000069 & 1.09 & 0.40 & 1.28 & 0.14 \\
\hline ESAM & 8.32 & $<0.00001$ & 3.76 & 0.0041 & 6.04 & 0.0022 \\
\hline LGALS1 & 1.5 & 0.020 & 2.2 & 0.044 & 1.8 & 0.051 \\
\hline MTA2 & 1.9 & 0.14 & 1.1 & 0.25 & 1.5 & 0.16 \\
\hline B4GALT6 & 1.0 & 0.45 & 1.4 & 0.12 & 1.2 & 0.20 \\
\hline CTTN & 4.7 & 0.0024 & 1.8 & 0.025 & 3.3 & 0.031 \\
\hline SRGN & 1.8 & 0.097 & 13.6 & 0.00024 & 7.7 & 0.053 \\
\hline
\end{tabular}

Data in italics are not statistically significant
By immunohistochemical staining, we could confirm some of these gene products like MTA2, ESAM, and LGALS1 in primary tumour and in metastasized cells in the lung of the two clones (Fig. $4 \mathrm{a}-\mathrm{c}$ ), but CTTN only in primary tumour sections not in metastatic cells of the lung (Fig. 4d).
Further evaluating the microarray data of the scid and the select group, we observed that many genes which are crucial for glycosylation show an altered expression: for example, MAN1A1, MAN2A1, and GALNT 5 and 7 were downregulated in Fra-2 cl 1 scid primary tumours, whereas MGAT4A was upregulated. ST8SIA4, B4GALT5, 
Fig. 4 a-d IHC staining of selected upregulated proteins in representative lung tissue grown in select mice injected with Fra- 2 clones showing a higher immunoreactivity of MTA2 (p <), ESAM (b), and LGALS1 (Galectin-1) (c) in the metastasized cells. Scale bar: $200-50 \mu \mathrm{m}$. Arrows label metastasized cells in the lungs. d IHC staining of primary tumour resected from select mice injected with Fra- 2 clone 2 with CTTN-positive tumour cells. Scale bar: $500-100 \mu \mathrm{m}$

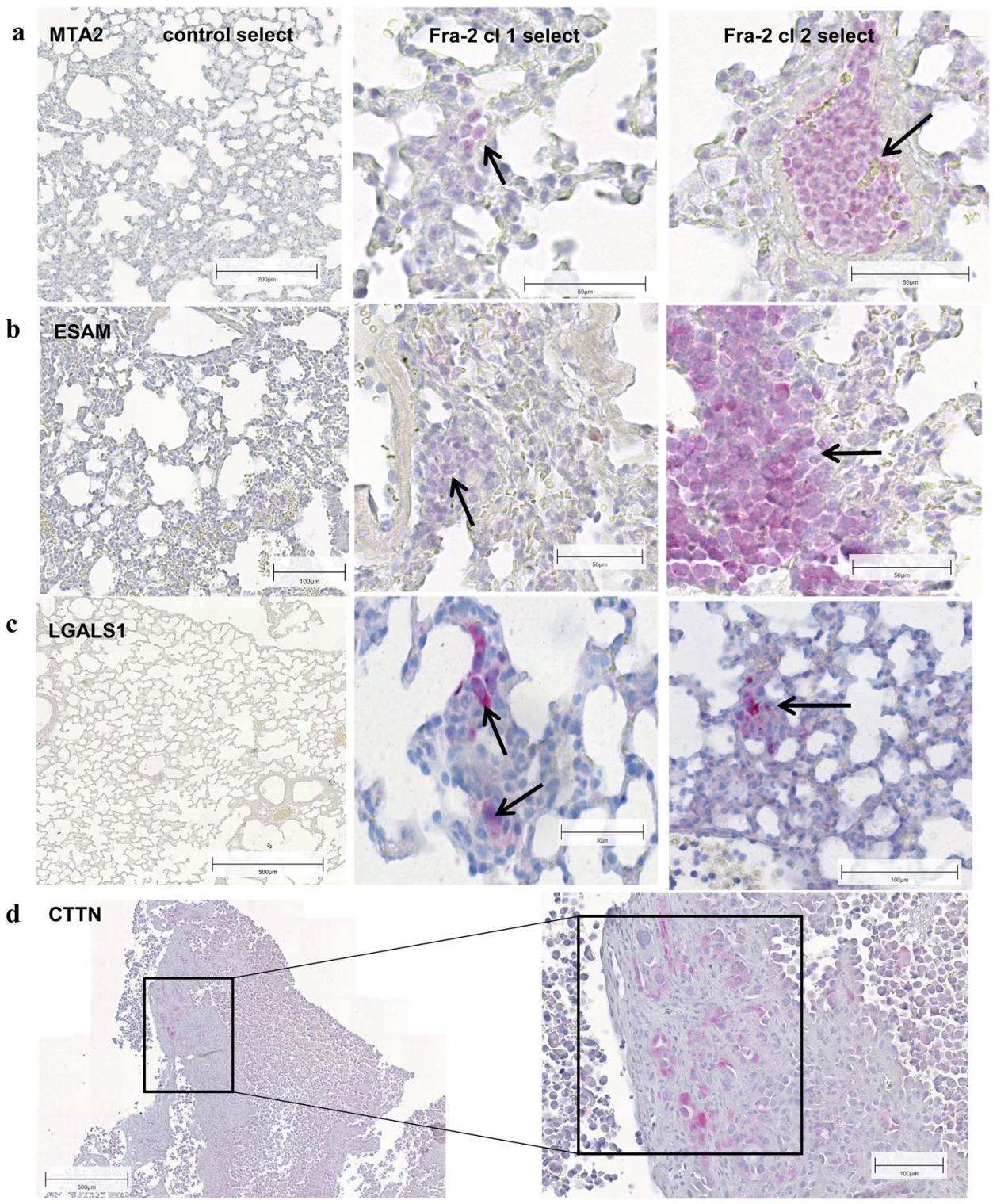

and CSGALNACT2 were found to be downregulated in Fra-2 cl 2 scid primary tumours.

LGALS1, B4GALT6, and GALNT11 were upregulated and MGAT5, MAN1A1, MANBA, LUM, GALNT1 and 7, HAPLN3, and ST6GALNAC5 were downregulated in Fra-2 cl 1 select primary tumours, while $M G A T 4 A$ was upregulated.

Table 4 is included in a separate file.

\section{Discussion}

The aim of the present experimental study was to elucidate the functional consequences of Fra- 2 overexpression for the formation of metastases in a spontaneous breast cancer metastasis model. So far, only clinical and in vitro data were available, which showed that Fra-2 overexpression is associated with a significantly shorter disease-free survival for breast cancer patients and in Fra- 2 overexpressing cell lines Fra-2 dysregulates genes involved in cell-cell and cell-matrix contacts (Schroder et al. 2010; Milde-Langosch et al. 2008).

Our results from the present scid mouse models demonstrate that Fra- 2 overexpression in the injected breast cancer cells leads to a significantly shorter overall survival of the mice, and in accordance with this observation, a considerable and significantly higher number of microscopically detectable metastasis was detected in the animals' lungs (Fig. 1e-m). To identify the genes involved in this enhanced metastatic capacity, cDNA microarray analysis of resected primary scid mouse xenograft tumours was performed which identified a considerable number of dysregulated genes, which are known to be involved in metastasis formation. 
The attachment of the tumour cells to endothelium is the crucial step during metastasis formation, which is characterized by enhanced adhesive properties of the circulating cells by upregulation of cell-adhesion molecules and their ligands, respectively. The general steps of the metastatic cascade can be divided into several phases. The extravasation of tumour cells is initialized by rolling and low-affinity binding at the endothelium mediated by the selectin family. Rolling is followed by tight adhesion through integrins or other members of the large family of adhesion molecules. As cell-to-cell and cell-to-matrix adhesion molecules had been identified to be rate limiting for metastasis formation, we focused on this class of molecules (Gebauer et al. 2013; Kohler et al. 2010; Oliveira-Ferrer et al. 2015; OliveiraFerrer et al. 2014). Supporting our former in vitro study (Schroder et al. 2010), we found a higher mRNA expression of the immunoglobulin superfamily cell-adhesion molecule L1-CAM in isolated Fra-2 $\mathrm{cl} 1$ scid primary tumours, which could be confirmed by Western blot (Fig. 2a) and IHC analysis including primary tumour sections and metastasized cells in the lungs (Fig. 3a). The expression of L1-CAM is induced by ERK-MAP-kinase signaling (Schaefer et al. 1999; Silletti et al. 2004) and MAP/ERK has been shown to be an important upstream regulator of AP-1 signaling (Eferl and Wagner 2003). Mechanistically, Fra-2, as heterodimer with a Jun partner, binds conserved AP-1 consensus sites at the L1-CAM promoter and is able to mediate transcriptional activation of L1-CAM when Fra-2 is phosphorylated by ERK-1/2 (Geismann et al. 2009). Results from Dippel et al. indicate that L1-CAM expression on MDA MB231 cells promotes adherence to activated endothelial cells by binding to endothelial L1-CAM (Dippel et al. 2013). Enhanced expression resulted in L1-CAM mediated cell adhesion, migration, and proliferation, thereby contributing to tumour progression and invasiveness. In nearly all malignancies investigated so far, L1-CAM expression was associated with poor prognosis, tumour progression, and metastasis to lymph nodes (Altevogt et al. 2016). A key player in this step of the metastatic cascade is ICAM-1, of which we confirmed a higher expression in the isolated Fra- $2 \mathrm{cl} 2$ scid primary tumours by Western blot (Fig. 2a) and IHC analysis (Fig. 3b). ICAM-1 mediates the adhesion of lymphocytes to endothelial cells (Lawson and Wolf 2009) via Integrin $\alpha \mathrm{L} \beta 2$ (LFA-1) (Simon et al. 2000). As tumour cells do not express $\alpha \mathrm{L} \beta 2$ integrins, they use leukocytes as linker cells to adhere to the vascular endothelium by means of an ICAM-1/ LFA-1 interaction (Strell and Entschladen 2008). It has been shown that MDA MB468 breast cancer cells use this mechanism to adhere to lung endothelial cells (Strell et al. 2007). Furthermore, ICAM-1 expression correlated with the metastatic capacity of five human breast cancer cell lines, suggesting its key role in invasion and dissemination (Rosette et al. 2005). As ICAM-1 contain AP-1 binding sites within their promoter regions, ICAM-1 engagement leads to downstream activation of the MAP-and ERK-1 kinase cascade and subsequent AP-1 transcription factor activity (Hubbard and Rothlein 2000; Lawson et al. 1999). Another member of this immunoglobulin superfamily, namely CD44, was also upregulated by Fra-2 as well in the scid mouse xenograft tumours and metastasized cells in the lungs as confirmed by Western blot (Fig. 2a) and immunohistochemistry (Fig. 3c). CD44 is a cell-surface glycoprotein with a postulated role in cancer metastasis (Marhaba and Zoller 2004) with binding domains for hyaluronan and other glycosaminoglycans, collagen, laminin, and fibronectin, all components of the ECM (Herrera-Gayol and Jothy 1999).

Overexpression of CD44 has been linked to a number of transcription factors including NFkB and AP-1 (Foster et al. 2000). Most notably, AP-1 has been shown to have a direct effect on CD44 expression by binding the CD44 promoter (Mandal et al. 2011; Smith and Cai 2012). In colon carcinoma cells O-glycosylated CD44 can bind endothelial E-selectin, which in turns contributes to metastasis (Hanley et al. 2005). Following the steps of the metastatic cascade, integrins like ITGB4, which was highly expressed in Fra-2 overexpressing scid tumours, are also O-glycosylated and are suspected to influence the attachment of tumour cells to the ECM as well as cell-to-cell interactions (Oliveira-Ferrer et al. 2017). Moreover, ITGB4 transactivates EGFR/Her2 signaling and promotes lung metastasis in breast cancer cells (Abdel-Ghany et al. 2001; Yoon et al. 2006). It stimulates mammary carcinoma hyper proliferation by inducing phosphorylation and, presumably, activation of c-Jun, the preferred dimer partner of Fra-2 (Eferl and Wagner 2003; Foletta 1996). In agreement with our previous in vitro study (Schroder et al. 2010), we could substantiate the expression of L1-CAM, ICAM-1, and CD44 in the scid mouse model injected with Fra-2 overexpressing cells. Furthermore, we found metastasized cells expressing L1-CAM, ICAM-1, CD44, ITGB4, and TSPAN8 in corresponding lungs of those scid mice (Fig. 3a-e). Mechanistically, the above-named results imply that Fra-2 participates in the metastatic cascade by regulating signaling functions and ligand interactions of these genes.

This special role of Fra-2 also becomes clear in the second experimental approach. We were able to show that the select mice had a survival advantage to the scid mice and a reduced metastatic load in the lung, but nevertheless, tumour growth and metastasis did occur at a later time point. This growth delay can be explained by the lack of E- and P-selectins on the endothelium of the select mice, as the initial contact and adherence of the tumour cells to the endothelium is hampered and thus gives the mice a survival advantage of about 30 days. However, our studies also demonstrate that the transcription factor Fra-2 is able to control the expression of other adhesion molecules as well (L1-CAM, ICAM-1, 
$\mathbf{a}$

Fra-2 mediated adhesion in scid mice

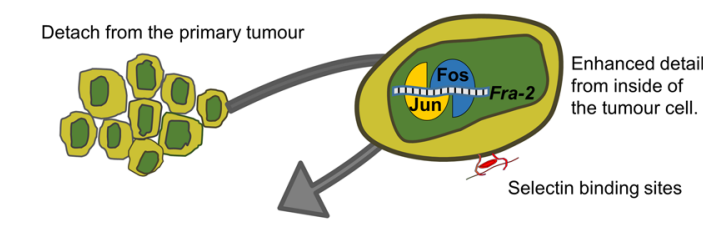

Intravasation

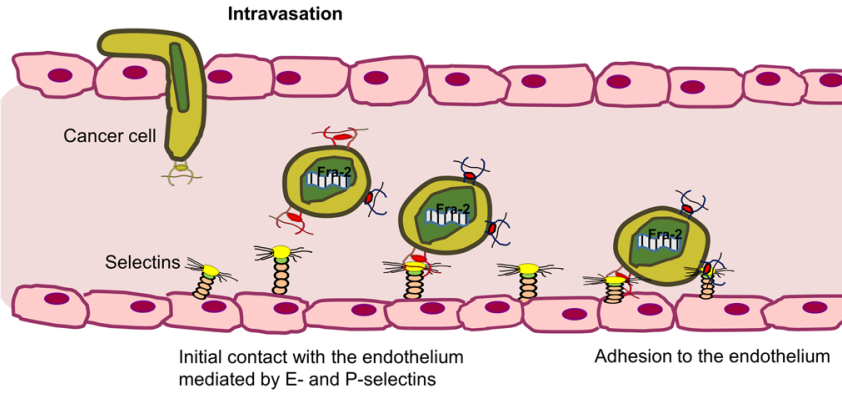

b

Fra-2 mediated adhesion in select mice without E-P-selectins

Detach from the primary tumour

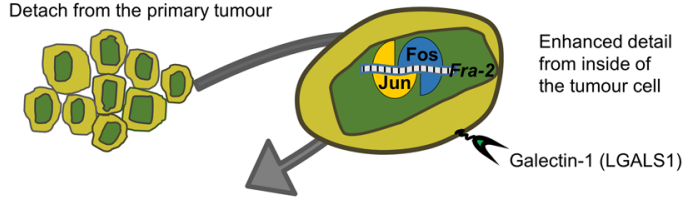

Intravasation

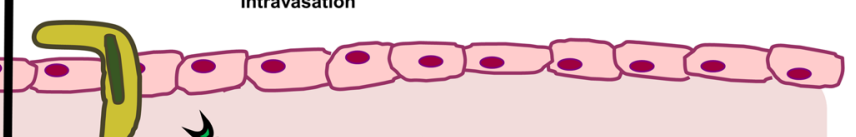

(1)

Initial contact with the

endothellum mediated

in the select mice.

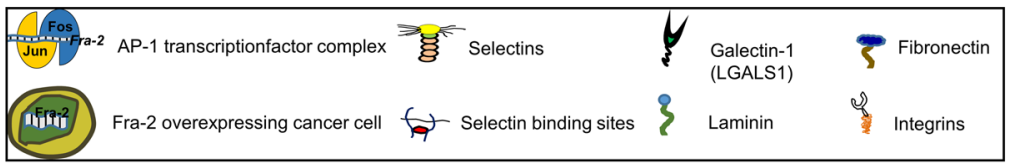

Fig. 5 Schematic representation of the main findings of this work: possible mechanism of selectin-dependent in scid mice and selectinindependent in select mice cancer cell adhesion driven by Fra-2. This figure shows the ambivalent function of Fra-2-controlled adhesion in cancer metastasis. a When selectins are expressed on the luminal surface of endothelial cells, the Fra-2 induced (over)expression of selectin ligand carrying glycoproteins (L1-CAM, ICAM-1, or also CD44 and ITBG4) leads to an increased number of spontaneous metastases in the lungs and a shorter survival. b How this process could take place in a selectin knock-out mouse. Selectins are the first port of call

CD44, ITGB4, and TSPAN8) and thus allows the tumour cells to adhere to the selectin-deficient endothelium via these adhesion molecules. Again, microarray analyses of resected tumours of the select mice were performed to identify possible genes that would assure adhesion to the endothelium in the absence of selectin-binding partners.

Based on the microarray data, LGALS1, also known as Galectin-1, exhibited the most significant upregulation. Its transcript was clearly upregulated in tumours resected from select mice injected with Fra- $2 \mathrm{cl} 1$ as well as cl 2 (Table 4) and we were able to detect the expression of LGALS1 by immunohistochemistry both in the tumours and in metastatic cells in the lungs of animals of both Fra-2 overexpressing clones (Fig. 4c). Galectin-1 is a non-covalent homodimeric galectin, which preferentially recognizes Gal $\beta 1$, 4GlcNAC (LacNAc) sequences, which can be present on $N$ - or $O$-linked glycans (Elola et al. 2005). Galectin-1 affects the interaction of tumour cells with endothelial cells, which is critical in invasion and metastasis (Kuwabara et al. 2003). Galectin-1 has been observed to arbitrate the adhesion of in the leukocyte adhesion cascade, which is however, redundantly organized. Next to selectins integrins and cell-adhesion molecules of the immunoglobulin superfamily follow. This lack of selectins now selects cell adhesion molecules other the selectin ligands on the cancer cells such as Galectin-1 ( $L G A L S 1)$, which is also upregulated by Fra-2. The tumour cells presumably come into contact through an interaction of Galectin-1 (LGALS1) with fibronectin, laminin, or integrins, and thus mediate the adhesion to the endothelium. This leads to a significantly delayed adhesion and provides the mice a considerable survival advantage

cancer cells to the ECM; laminin, fibronectin, and other glycoproteins presented in the basement membrane provide the necessary epitopes for Galectin-1-cell-ECM cross-linking (Cousin and Cloninger 2016; Jeschke et al. 2006; Brule et al. 1995). Nam et al. confirmed the binding of Galectin-1 to the cell surface via its interaction with ITGB1 in MDA MB231 cells (Nam et al. 2017). As Galectin-1 expression is at least in part dependent on the constitutive activation of the AP1 transcription complex, it is one more member of celladhesion molecules regulated by AP-1 transcription factors (Juszczynski et al. 2007). In summary, this study shows that the transcription factor Fra- 2 by virtue of its multiple properties can activate genes involved in cell adhesion at either the receptor or ligand level, thus promoting adhesion to the endothelium and tumour metastasis. This even takes place in the absence of initial molecules, such as selectins, by activation of other downstream genes which launch the adhesion. A possible mechanism of the role of Fra-2 in our mouse model is shown in Fig. 5. Even though Fra-2 appears to be an essential component in the metastasis process through 
the regulation of several adhesion molecules, it is difficult to envisage Fra-2 as a potential therapeutic target because of its multiple interactions in its function as a transcription factor. Deletion of Fra-2 leads to an early lethality in mice: at birth, knock-out puppies suffer from a severe growth defect and die within the first week (Eferl et al. 2007). Our results furthermore show that the transcription factor Fra-2 plays an ambivalent function in the metastasis of breast cancer. In the presence of selectins, Fra-2 promotes the adhesion of tumour cells to the endothelium due to its influence on the expression of selectin ligands as shown in our in vitro studies (Schroder et al. 2010). Yet, as shown in select mice, Fra-2 can also promote metastasis in the absence of selectins, although more slowly, by activation of selectin-independent adhesion processes. This finding highlights the important role of Fra-2 as a regulator of CAMs of adhesion cascade in breast cancer metastasis.

Supplementary Information The online version contains supplementary material available at https://doi.org/10.1007/s00432-021-03812-2.

Acknowledgements We are grateful for the excellent technical assistance of Tobias Gosau, Jennifer Schroeder-Schwarz, and Christine Knies.

Author contributions Conceptualization: KML, US, and CS. Methodology: SA, JK, DVM, and CS. Data acquisition/analysis: SA, JK, DVM, SAN TRS, SL, KML, DW, AGT, and CS. Wrote the manuscript: SA, DW, US, and CS. Figures: SA and CS. Supervision: KML, DW, CS, and US. All authors reviewed the Manuscript.

Funding Open Access funding enabled and organized by Projekt DEAL. The research was partially supported by the HSE University Basic Research Program (Diana V. Maltseva, Stepan A. Nersisyan) and by the Russian Science Foundation project 17-14-01338 (Alexander G. Tonevitsky).

Data availability The datasets generated during and/or during the current study are available from the corresponding author on reasonable request. The raw data were deposited in the Gene Expression Omnibus database (www.ncbi.nlm.nih.gov/geo/) under Accession No. GSE148089.

Code availability No code.

\section{Declarations}

Conflict of interest The authors declare that they have no competing interests.

Open Access This article is licensed under a Creative Commons Attribution 4.0 International License, which permits use, sharing, adaptation, distribution and reproduction in any medium or format, as long as you give appropriate credit to the original author(s) and the source, provide a link to the Creative Commons licence, and indicate if changes were made. The images or other third party material in this article are included in the article's Creative Commons licence, unless indicated otherwise in a credit line to the material. If material is not included in the article's Creative Commons licence and your intended use is not permitted by statutory regulation or exceeds the permitted use, you will need to obtain permission directly from the copyright holder. To view a copy of this licence, visit http://creativecommons.org/licenses/by/4.0/.

\section{References}

Abdel-Ghany M, Cheng HC, Elble RC, Pauli BU (2001) The breast cancer beta 4 integrin and endothelial human CLCA2 mediate lung metastasis. J Biol Chem 276:25438-25446. https://doi.org/ 10.1074/jbc.M100478200

Altevogt P, Doberstein K, Fogel M (2016) L1CAM in human cancer. Int J Cancer 138:1565-1576. https://doi.org/10.1002/ijc.29658

Angel P, Karin M (1991) The role of Jun, Fos and the AP-1 complex in cell-proliferation and transformation. Biochim Biophys Acta 1072:129-157

Borsig L (2018) Selectins in cancer immunity. Glycobiology 28:648655. https://doi.org/10.1093/glycob/cwx105

Bozec A et al (2013) Osteoblast-specific expression of Fra-2/AP-1 controls adiponectin and osteocalcin expression and affects metabolism. J Cell Sci 126:5432-5440. https://doi.org/10.1242/ jcs. 134510

Carr I, Orr FW (1983) Invasion and metastasis. Can Med Assoc J 128:1164-1167

Cousin JM, Cloninger MJ (2016) The role of Galectin-1 in cancer progression, and synthetic multivalent systems for the study of galectin-1. Int J Mol Sci. https://doi.org/10.3390/ijms 17091566

da Huang W, Sherman BT, Lempicki RA (2009) Systematic and integrative analysis of large gene lists using DAVID bioinformatics resources. Nat Protoc 4:44-57. https://doi.org/10.1038/nprot. 2008.211

Dippel V et al (2013) Influence of L1-CAM expression of breast cancer cells on adhesion to endothelial cells. J Cancer Res Clin Oncol 139:107-121. https://doi.org/10.1007/s00432-012-1306-z

Ebeling O et al (1996) L1 adhesion molecule on human lymphocytes and monocytes: expression and involvement in binding to alpha v beta 3 integrin. Eur J Immunol 26:2508-2516. https://doi.org/ 10.1002/eji.1830261035

Eccles SA et al (2013) Critical research gaps and translational priorities for the successful prevention and treatment of breast cancer. Breast Cancer Res 15:R92. https://doi.org/10.1186/bcr3493

Eferl R, Wagner EF (2003) AP-1: a double-edged sword in tumorigenesis. Nat Rev Cancer 3:859-868. https://doi.org/10.1038/nrc1209

Eferl R, Zenz R, Theussl HC, Wagner EF (2007) Simultaneous generation of fra- 2 conditional and fra- 2 knock-out mice. Genesis 45:447-451. https://doi.org/10.1002/dvg.20311

Elola MT, Chiesa ME, Alberti AF, Mordoh J, Fink NE (2005) Galectin-1 receptors in different cell types. J Biomed Sci 12:13-29. https://doi.org/10.1007/s11373-004-8169-5

Engel L et al (2005) Fos-related antigen 2 (Fra-2) memorizes photoperiod in the rat pineal gland. Neuroscience 132:511-518. https:// doi.org/10.1016/j.neuroscience.2004.12.014

Fidler IJ (1978) Tumor heterogeneity and the biology of cancer invasion and metastasis. Cancer Res 38:2651-2660

Fidler IJ (2003) The pathogenesis of cancer metastasis: the "seed and soil" hypothesis revisited. Nat Rev Cancer 3:453-458. https://doi. org/10.1038/nrc1098

Foletta VC (1996) Transcription factor AP-1, and the role of Fra-2. Immunol Cell Biol 74:121-133. https://doi.org/10.1038/icb.1996. 17

Foster LC et al (2000) Role of activating protein-1 and high mobility group-I(Y) protein in the induction of CD44 gene expression by interleukin-1beta in vascular smooth muscle cells. FASEB J 14:368-378. https://doi.org/10.1096/fasebj.14.2.368 
Gebauer F et al (2013) Selectin binding is essential for peritoneal carcinomatosis in a xenograft model of human pancreatic adenocarcinoma in pfp-/rag2- mice. Gut 62:741-750. https://doi.org/10. 1136/gutjnl-2011-300629

Geismann C et al (2009) Up-regulation of L1CAM in pancreatic duct cells is transforming growth factor beta1- and slug-dependent: role in malignant transformation of pancreatic cancer. Cancer Res 69:4517-4526. https://doi.org/10.1158/0008-5472.CAN-08-3493

Goetz J, Chatton B, Mattei MG, Kedinger C (1996) Structure and expression of the ATFa gene. J Biol Chem 271:29589-29598

Gout S, Tremblay PL, Huot J (2008) Selectins and selectin ligands in extravasation of cancer cells and organ selectivity of metastasis. Clin Exp Metastasis 25:335-344. https://doi.org/10.1007/ s10585-007-9096-4

Gupta S et al (2015) Selective participation of c-Jun with Fra-2/cFos promotes aggressive tumor phenotypes and poor prognosis in tongue cancer. Sci Rep 5:16811. https://doi.org/10.1038/srep1 6811

Hanley WD, Burdick MM, Konstantopoulos K, Sackstein R (2005) CD44 on LS174T colon carcinoma cells possesses E-selectin ligand activity. Cancer Res 65:5812-5817. https://doi.org/10. 1158/0008-5472.CAN-04-4557

Herrera-Gayol A, Jothy S (1999) Adhesion proteins in the biology of breast cancer: contribution of CD44. Exp Mol Pathol 66:149-156. https://doi.org/10.1006/exmp.1999.2251

Hubbard AK, Rothlein R (2000) Intercellular adhesion molecule-1 (ICAM-1) expression and cell signaling cascades. Free Radic Biol Med 28:1379-1386. https://doi.org/10.1016/s0891-5849(00) 00223-9

Jeschke U et al (2006) Binding of galectin-1 (gal-1) to the ThomsenFriedenreich (TF) antigen on trophoblast cells and inhibition of proliferation of trophoblast tumor cells in vitro by gal-1 or an anti-TF antibody. Histochem Cell Biol 126:437-444. https://doi. org/10.1007/s00418-006-0178-1

Jojovic M, Schumacher U (2000) Quantitative assessment of spontaneous lung metastases of human HT29 colon cancer cells transplanted into SCID mice. Cancer Lett 152:151-156

Juszczynski P et al (2007) The AP1-dependent secretion of galectin-1 by Reed Sternberg cells fosters immune privilege in classical Hodgkin lymphoma. Proc Natl Acad Sci USA 104:13134-13139. https://doi.org/10.1073/pnas.0706017104

Khaustova NA et al (2017) Selectin-independent adhesion during ovarian cancer metastasis. Biochimie 142:197-206. https://doi.org/10. 1016/j.biochi.2017.09.009

Kohler S, Ullrich S, Richter U, Schumacher U (2010) E-/P-selectins and colon carcinoma metastasis: first in vivo evidence for their crucial role in a clinically relevant model of spontaneous metastasis formation in the lung. Br J Cancer 102:602-609. https://doi. org/10.1038/sj.bjc.6605492

Kudriaeva A et al (2017) The transcriptome of type I murine astrocytes under interferon-gamma exposure and remyelination stimulus. Molecules. https://doi.org/10.3390/molecules22050808

Kuwabara I, Sano H, Liu FT (2003) Functions of galectins in cell adhesion and chemotaxis. Methods Enzymol 363:532-552. https://doi. org/10.1016/S0076-6879(03)01078-4

Lawson C, Wolf S (2009) ICAM-1 signaling in endothelial cells. Pharmacol Rep 61:22-32

Lawson C, Ainsworth M, Yacoub M, Rose M (1999) Ligation of ICAM-1 on endothelial cells leads to expression of VCAM-1 via a nuclear factor-kappaB-independent mechanism. J Immunol 162:2990-2996

Livak KJ, Schmittgen TD (2001) Analysis of relative gene expression data using real-time quantitative PCR and the 2(-Delta Delta C(T)) Method. Methods 25:402-408. https://doi.org/10.1006/ meth.2001.1262
Maltseva DV et al (2013) High-throughput identification of reference genes for research and clinical RT-qPCR analysis of breast cancer samples. J Clin Bioinforma 3:13. https://doi.org/10.1186/ 2043-9113-3-13

Mandal CC, Ghosh-Choudhury N, Yoneda T, Choudhury GG, GhoshChoudhury N (2011) Simvastatin prevents skeletal metastasis of breast cancer by an antagonistic interplay between p53 and CD44. J Biol Chem 286:11314-11327. https://doi.org/10.1074/ jbc.M110.193714

Marhaba R, Zoller M (2004) CD44 in cancer progression: adhesion, migration and growth regulation. J Mol Histol 35:211-231

Maruya S et al (2004) Gene expression screening of salivary gland neoplasms: molecular markers of potential histogenetic and clinical significance. J Mol Diagn 6:180-190. https://doi.org/10.1016/ s1525-1578(10)60508-9

Milde-Langosch K (2005) The Fos family of transcription factors and their role in tumourigenesis. Eur J Cancer 41:2449-2461. https:// doi.org/10.1016/j.ejca.2005.08.008

Milde-Langosch K et al (2008) Role of Fra-2 in breast cancer: influence on tumor cell invasion and motility. Breast Cancer Res Treat 107:337-347. https://doi.org/10.1007/s10549-007-9559-y

Nakayama T et al (2008) Aberrant expression of Fra-2 promotes CCR4 expression and cell proliferation in adult T-cell leukemia. Oncogene 27:3221-3232. https://doi.org/10.1038/sj.onc.1210984

Nakayama T, Higuchi T, Oiso N, Kawada A, Yoshie O (2012) Expression and function of FRA2/JUND in cutaneous T-cell lymphomas. Anticancer Res 32:1367-1373

Nam K et al (2017) Binding of galectin-1 to integrin beta1 potentiates drug resistance by promoting survivin expression in breast cancer cells. Oncotarget 8:35804-35823. https://doi.org/10.18632/oncot arget. 16208

Nehmann N, Wicklein D, Schumacher U, Muller R (2010) Comparison of two techniques for the screening of human tumor cells in mouse blood: quantitative real-time polymerase chain reaction (qRT-PCR) versus laser scanning cytometry (LSC). Acta Histochem 112:489-496. https://doi.org/10.1016/j.acthis.2009.05.004

Oliveira-Ferrer L et al (2014) c-FOS suppresses ovarian cancer progression by changing adhesion. Br J Cancer 110:753-763. https:// doi.org/10.1038/bjc.2013.774

Oliveira-Ferrer L et al (2015) Prognostic impact of transcription factor Fra-1 in ER-positive breast cancer: contribution to a metastatic phenotype through modulation of tumor cell adhesive properties. J Cancer Res Clin Oncol 141:1715-1726. https://doi.org/10.1007/ s00432-015-1925-2

Oliveira-Ferrer L, Legler K, Milde-Langosch K (2017) Role of protein glycosylation in cancer metastasis. Semin Cancer Biol 44:141152. https://doi.org/10.1016/j.semcancer.2017.03.002

Pantel K, Brakenhoff RH (2004) Dissecting the metastatic cascade. Nat Rev Cancer 4:448-456. https://doi.org/10.1038/nrc1370

Percie du Sert N et al (2020) The ARRIVE guidelines 20: updated guidelines for reporting animal research. J Physiol 598:37933801. https://doi.org/10.1113/JP280389

Ritchie ME et al (2015) limma powers differential expression analyses for RNA-sequencing and microarray studies. Nucleic Acids Res 43:e47. https://doi.org/10.1093/nar/gkv007

Rosette C et al (2005) Role of ICAM1 in invasion of human breast cancer cells. Carcinogenesis 26:943-950. https://doi.org/10.1093/ carcin/bgi070

Roy S et al (2010) Fra-2 mediates oxygen-sensitive induction of transforming growth factor beta in cardiac fibroblasts. Cardiovasc Res 87:647-655. https://doi.org/10.1093/cvr/cvq123

Sakharov DA et al (2012) Passing the anaerobic threshold is associated with substantial changes in the gene expression profile in white blood cells. Eur J Appl Physiol 112:963-972. https://doi.org/10. 1007/s00421-011-2048-3 
Schaefer AW et al (1999) Activation of the MAPK signal cascade by the neural cell adhesion molecule L1 requires L1 internalization. J Biol Chem 274:37965-37973

Schroder C et al (2009) Expression and prognostic value of L1-CAM in breast cancer. Oncol Rep 22:1109-1117

Schroder C et al (2010) The transcription factor Fra-2 promotes mammary tumour progression by changing the adhesive properties of breast cancer cells. Eur J Cancer 46:1650-1660. https://doi.org/ 10.1016/j.ejca.2010.02.008

Silletti S et al (2004) Extracellular signal-regulated kinase (ERK)dependent gene expression contributes to L1 cell adhesion molecule-dependent motility and invasion. J Biol Chem 279:2888028888. https://doi.org/10.1074/jbc.M404075200

Simon SI, Hu Y, Vestweber D, Smith CW (2000) Neutrophil tethering on E-selectin activates beta 2 integrin binding to ICAM-1 through a mitogen-activated protein kinase signal transduction pathway. J Immunol 164:4348-4358. https://doi.org/10.4049/jimmunol. 164.8 .4348

Smith SM, Cai L (2012) Cell specific CD44 expression in breast cancer requires the interaction of AP-1 and NFkappaB with a novel cis-element. PLoS ONE 7:e50867. https://doi.org/10.1371/journ al.pone. 0050867

Strell C, Entschladen F (2008) Extravasation of leukocytes in comparison to tumor cells. Cell Commun Signal 6:10. https://doi.org/10. 1186/1478-811X-6-10

Strell C, Lang K, Niggemann B, Zaenker KS, Entschladen F (2007) Surface molecules regulating rolling and adhesion to endothelium of neutrophil granulocytes and MDA-MB-468 breast carcinoma cells and their interaction. Cell Mol Life Sci 64:3306-3316. https://doi.org/10.1007/s00018-007-7402-6

Stubke K, Wicklein D, Herich L, Schumacher U, Nehmann N (2012) Selectin-deficiency reduces the number of spontaneous metastases in a xenograft model of human breast cancer. Cancer Lett 321:89-99. https://doi.org/10.1016/j.canlet.2012.02.019
Tremblay PL, Auger FA, Huot J (2006) Regulation of transendothelial migration of colon cancer cells by E-selectin-mediated activation of p38 and ERK MAP kinases. Oncogene 25:6563-6573. https:// doi.org/10.1038/sj.onc.1209664

van den Brule FA et al (1995) Galectin-1 modulates human melanoma cell adhesion to laminin. Biochem Biophys Res Commun 209:760-767. https://doi.org/10.1006/bbrc.1995.1564

Varki A (1997) Selectin ligands: will the real ones please stand up? J Clin Invest 100:S31-35

Vogt PK, Bos TJ (1990) jun: oncogene and transcription factor. Adv Cancer Res 55:1-35

Wang J et al (2014) FOSL2 positively regulates TGF-beta1 signalling in non-small cell lung cancer. PLoS ONE 9:e112150. https://doi. org/10.1371/journal.pone.0112150

Workman P et al (2010) Guidelines for the welfare and use of animals in cancer research. Br J Cancer 102:1555-1577. https://doi.org/ 10.1038/sj.bjc.6605642

Yoon SO, Shin S, Lipscomb EA (2006) A novel mechanism for integrin-mediated ras activation in breast carcinoma cells: the alpha6beta4 integrin regulates ErbB2 translation and transactivates epidermal growth factor receptor/ErbB2 signaling. Cancer Res 66:2732-2739. https://doi.org/10.1158/0008-5472.CAN-05-2941

Zhang W, Hart J, McLeod HL, Wang HL (2005) Differential expression of the AP-1 transcription factor family members in human colorectal epithelial and neuroendocrine neoplasms. Am J Clin Pathol 124:11-19. https://doi.org/10.1309/T1H2Y2CHWY7PD2BN

Publisher's Note Springer Nature remains neutral with regard to jurisdictional claims in published maps and institutional affiliations.

\section{Authors and Affiliations}

\section{Sabrina Arnold ${ }^{1}$. Jan Kortland ${ }^{1}$. Diana V. Maltseva ${ }^{2}$. Stepan A. Nersisyan ${ }^{2}$. Timur R. Samatov ${ }^{4} \cdot$ Susanne Lezius $^{5}$. Alexander G. Tonevitsky ${ }^{2,3} \cdot$ Karin Milde-Langosch $^{6} \cdot$ Daniel Wicklein $^{1} \cdot$ Udo Schumacher $^{1} \cdot$ Christine Stürken $^{1}$}

\author{
Sabrina Arnold \\ arnold.sabrina@gmx.de \\ Jan Kortland \\ jankortland@gmail.com \\ Diana V. Maltseva \\ dmaltseva@gmail.com \\ Timur R. Samatov \\ timur.samatov@gmail.com \\ Susanne Lezius \\ s.lezius@uke.de \\ Alexander G. Tonevitsky \\ tonevitsky@mail.ru \\ Karin Milde-Langosch \\ milde-langosch@gmx.de \\ Daniel Wicklein \\ d.wicklein@uke.de \\ Udo Schumacher \\ u.schumacher@uke.de
}

1 Institute of Anatomy and Experimental Morphology, University Cancer Center Hamburg, University Medical Center Hamburg-Eppendorf, Martinistrasse 52, 20246 Hamburg, Germany

2 Faculty of Biology and Biotechnology, National Research University Higher School of Economics, Myasnitskaya Str. 13/4, 117997 Moscow, Russia

3 Scientific Research Center Bioclinicum, Ugreshskaya Str. 2/85, 115088 Moscow, Russia

4 Evotec International GmbH, Marie-Curie-Str. 7, 37079 Göttingen, Germany

5 Department of Medical Biometry and Epidemiology, University Medical Center Hamburg-Eppendorf, Martinistrasse 52, 20246 Hamburg, Germany

6 Department of Gynecology, University Medical Center Hamburg-Eppendorf, Martinistrasse 52, 20246 Hamburg, Germany 